\title{
Hygroscopicity and chemical composition of Antarctic sub-micrometre aerosol particles and observations of new particle formation
}

\author{
E. Asmi ${ }^{1,2}$, A. Frey ${ }^{1}$, A. Virkkula ${ }^{1,2}$, M. Ehn ${ }^{2}$, H. E. Manninen ${ }^{2}$, H. Timonen ${ }^{1}$, O. Tolonen-Kivimäki ${ }^{1}$, M. Aurela ${ }^{1}$, \\ R. Hillamo ${ }^{1}$, and M. Kulmala ${ }^{2}$ \\ ${ }^{1}$ Finnish Meteorological Institute, Research and Development, P. O. Box 503, 00101 Helsinki, Finland \\ ${ }^{2}$ Department of Physics, University of Helsinki, P. O. Box 64, 00014 Helsinki, Finland
}

Received: 8 December 2009 - Published in Atmos. Chem. Phys. Discuss.: 17 December 2009

Revised: 22 April 2010 - Accepted: 3 May 2010 - Published: 6 May 2010

\begin{abstract}
The Antarctic near-coastal sub-micrometre aerosol particle features in summer were characterised based on measured data on aerosol hygroscopicity, size distributions, volatility and chemical ion and organic carbon mass concentrations. Hysplit model was used to calculate the history of the air masses to predict the particle origin. Additional measurements of meteorological parameters were utilised. The hygroscopic properties of particles mostly resembled those of marine aerosols. The measurements took place at $130 \mathrm{~km}$ from the Southern Ocean, which was the most significant factor affecting the particle properties. This is explained by the lack of additional sources on the continent of Antarctica. The Southern Ocean was thus a likely source of the particles and nucleating and condensing vapours. The particles were very hygroscopic (HGF 1.75 at $90 \mathrm{~nm}$ ) and very volatile. Most of the sub- $100 \mathrm{~nm}$ particle volume volatilised below $100^{\circ} \mathrm{C}$. Based on chemical data, particle hygroscopic and volatile properties were explained by a large fraction of non-neutralised sulphuric acid together with organic material. The hygroscopic growth factors assessed from chemical data were similar to measured. Hygroscopicity was higher in dry continental air masses compared with the moist marine air masses. This was explained by the aging of the marine organic species and lower methanesulphonic acid volume fraction together with the changes in the inorganic aerosol chemistry as the aerosol had travelled long time over the continental Antarctica. Special focus was
\end{abstract}

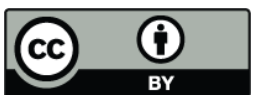

Correspondence to: E. Asmi (eija.asmi@fmi.fi) directed in detailed examination of the observed new particle formation events. Indications of the preference of negative over positive ions in nucleation could be detected. However, in a detailed case study, the neutral particles dominated the particle formation process. Freshly nucleated particles had the smallest hygroscopic growth factors, which increased subsequent to particle aging.

\section{Introduction}

Aerosol particle concentration, composition and dynamics in the atmosphere, are important to understand for predicting the particle climatic effects (e.g. Bellouin et al., 2005; Wang and Penner, 2009). Aerosol particle hygroscopic properties affect both directly (Martin et al., 2004) and indirectly (Bilde and Svenningsson, 2004; McFiggans et al., 2006) the aerosol radiative effects. Additionally, particulate hygroscopicity and volatility can be used as indirect indicators of the particle chemical composition (Swietlicki et al., 2008; Svenningsson et al., 2006; Johnson et al., 2004).

Although the physical and chemical properties of Antarctic aerosol particles have been widely studied (Hillamo et al., 1998; Koponen et al., 2003; Park et al., 2004; Shaw, 1988; Teinilä et al., 2000; Virkkula et al., 2006b), the knowledge on these particles is yet partly inadequate. Strong seasonal and spatial variation of aerosol concentrations and composition (Adams et al., 1999; Ito, 1989; Shaw, 1988) additionally complicate the overall characterisation of the Antarctic aerosol features. Several studies suggest that the composition of the Antarctic sub-micrometre particles is mainly

Published by Copernicus Publications on behalf of the European Geosciences Union. 
sulphuric acid partly neutralised by ammonia (Adams et al., 1999; Ito, 1989; O'Dowd et al., 1997; Shaw, 1988; Virkkula et al., 2006b). The sub-micrometre aerosol particle features should therefore be best characterised by a relatively simple sulphate chemistry.

Antarctica, because of its distance from anthropogenic sources, is an ideal place to study natural aerosol processes. Aerosol particle formation events, or precisely, growth of the tiny nanoparticles, are observed in numerous places around the world, including Antarctica (Kulmala et al. (2004) and references there in). Therefore, the source vapours for secondary particle formation and further condensational growth must exist there. Nucleation of particles has recently been linked to gaseous sulphuric acid, but organic material is required to explain the observed particle growth rates (e.g. Kulmala et al., 1998; Paasonen et al., 2009). Oceanic dimethyl sulphide (DMS) can be a source of sulphur dioxide in Antarctica, while the ocean can also be a source of both primary and secondary organics (Gantt et al., 2009; Gershey, 1983; O'Dowd et al., 2004; Spracklen et al., 2008). Kawamura et al. (1996) and Virkkula et al. (2006c) have observed organic carbon in aerosols in Antarctica. This gives a reason to presume a contribution of organics to particle chemistry in addition to the sulphate species.

The main aim of this research is to characterise the coastal Antarctic aerosol features in summer season. The particulate hygroscopicity and volatility have been examined together with the particle size distributions, chemical composition, relevant meteorology and modelled air mass origin to obtain information on the particle formation and growth processes, particle hygroscopic and CCN properties, particle chemistry, and short-term variability of these features. To our knowledge, these are the first aerosol hygroscopicity measurements made in Antarctica.

\section{Methods}

\subsection{Measurements}

We measured aerosol particle hygroscopicity, size distributions, chemical composition and volatility in Queen Maud Land, Antarctica. The measurements were conducted at the Finnish research station Aboa $\left(73^{\circ} 03^{\prime} \mathrm{S}, 13^{\circ} 25^{\prime} \mathrm{W}\right.$, Fig. 1) during the Antarctic summer 2006/2007 from 29 December to 29 January. The station is located about $130 \mathrm{~km}$ from the open sea on a nunatak Basen in the Vestfjella Mountains. The instruments were operated in an Aerosol Research Laboratory (ARL), about $250 \mathrm{~m}$ from the main station facing southwest, at an altitude of $496 \mathrm{~m}$ a.s.l. The opposite direction was declared as the contaminated sector $\left(200^{\circ}-275^{\circ}\right)$ due to diesel generator and motor vehicle emissions at the station. The data, measured during southwesterly winds from the contaminated sector were omitted from further analysis.

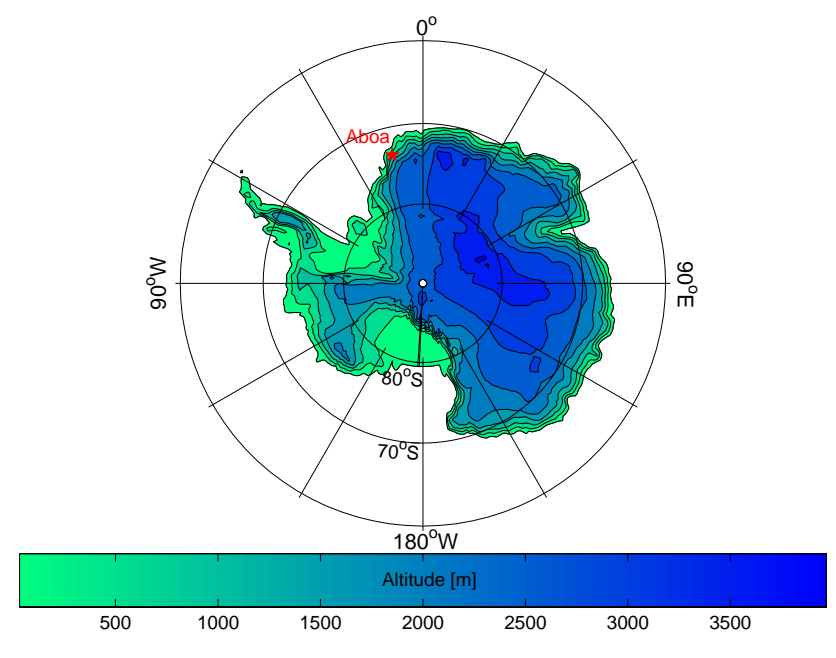

Fig. 1. Map of Antarctica where Aboa station is marked with a red star. The colourmap over the land areas presents the altitude in ma.s.l.

There are minor gaps in the data especially in the beginning of the measurement period due to technical problems and power failures. As a result, hygroscopicity data were available between 10 and 28 January. Volatility data exists only on 29 January. Chemical composition and size distribution data exist from whole January 2007.

\subsection{Instrumentation}

\subsubsection{Hygroscopicity and volatility}

Hygroscopic properties of $10,25,50$ and $90 \mathrm{~nm}$ particles were measured with a Hygroscopicity-Tandem Differential Mobility Analyser (H-TDMA). The details of the H-TDMA setup used are presented by Ehn et al. (2007a). The HTDMA sample air was taken from a $\mathrm{PM}_{1}$ inlet, extending $2 \mathrm{~m}$ above the roof with a total line length of $2.5 \mathrm{~m}$. Sample lines were built up of $6 \mathrm{~mm}$ stainless steel and copper tubes. The H-TDMA consisted of two Differential Mobility Analysers (DMA): a $10.9 \mathrm{~cm}$ long Hauke-type DMA1 selected the dry particle size and a subsequent differentially scanning $28.0 \mathrm{~cm}$ long Hauke-type DMA2 measured the humidified particle size distribution (Winklmayr et al., 1991; Knutson and Whitby, 1975). Both the aerosol and the sheath flow were humidified. The relative humidity $(\mathrm{RH})$ in the DMA2 was $90.0 \pm 0.5 \%$. Sheath flows, $6.0 \pm 0.2 \mathrm{LPM}$ in DMA1 and 10.0 \pm 0.1 LPM in DMA2, were controlled with needle valves. Both DMAs were operated in closed loops (Jokinen and Mäkelä, 1997). The residence time of the humidification was around $2 \mathrm{~s}$, and thus adequate for the such small particle sizes (Kerminen, 1997). The scanning time of the DMA2 was around $15 \mathrm{~min}$ per size and the distributions of the four particle sizes were measured in an hour. The sample flow rate was 1 LPM and prior to the H-TDMA a neutraliser (Ni-63, 
$370 \mathrm{MBq}$ ) was used to obtain a steady-state charge distribution. Particle numbers were measured with a TSI Condensation Particle Counter (CPC) model 3010 (Quant et al., 1992). Mobility distributions measured with DMA2 were inverted using functions by Stolzenburg (1988). Lognormal modes were fitted to the inverted humidified particle size distributions. The hygroscopic growth factors (HGF) were determined as the median size of the fitted mode divided by the dry particle size. For comparison, data from one day were inverted with the routine by Gysel (2009). The difference between the inverted spectra achieved using the two methods was insignificant. As the ARL had no air conditioning, the indoor temperature fluctuated. To maintain the measurement temperature of the H-TDMA constant, the DMA2 flows were in an isolated space equipped with air conditioning. The temperature of the DMA2 was kept in $20.0 \pm 1.0^{\circ} \mathrm{C}$.

Dry scans were performed before and after the measurements. Additionally, calibration scans with ammonium sulphate were made every second day. Results of the calibration scans are presented in Table 1.

For the last measurement day, 29 January, the aerosol humidifier was replaced by a thermodenuder to make VolatilityTandem Differential Mobility Analyser (V-TDMA) measurements. Details of the thermodenuder and the calibration are presented by Ehn et al. (2007b). Even though the thermodenuder losses depend on the temperature (Wehner et al., 2002), they were not corrected for two reasons: 1) The temperature range used was small, and 2) in V-TDMA, similarly as in H-TDMA, the absolute concentration is often insignificant as only the peak diameters of the distributions are examined. However, it should be stated that in case of an externally mixed aerosol there is a possibility that highly volatile particles are lost during heating. In this case, without knowing the total aerosol number after the first DMA, the volatility of the aerosol can be underestimated.

\subsubsection{Chemical sampling and analysis}

The size-segregated samples were taken using a 12-stage Small-Deposit-area low-pressure Impactor (SDI) (Maenhaut et al., 1996). The SDI flow rate was 11 LPM. Substrate material was polycarbonate (poreless polycarbonate film from Nuclepore, thickness $10 \mu \mathrm{m})$ punched to $21 \mathrm{~mm}$ diameter. The theoretical aerodynamic cut-off diameters $\left(D_{50}\right)$ of the SDI stages at $20^{\circ} \mathrm{C}$ and 1013 mbar are $0.045,0.086,0.15$, $0.23,0.34,0.59,0.80,1.06,1.66,2.68,4.08$, and $8.5 \mu \mathrm{m}$. The mass concentrations of sodium $\left(\mathrm{Na}^{+}\right)$, ammonium $\left(\mathrm{NH}_{4}^{+}\right)$, potassium $\left(\mathrm{K}^{+}\right)$, magnesium $\left(\mathrm{Mg}^{2+}\right)$, calcium $\left(\mathrm{Ca}^{2+}\right)$, chloride $\left(\mathrm{Cl}^{-}\right)$, nitrate $\left(\mathrm{NO}_{3}^{-}\right)$, sulfate $\left(\mathrm{SO}_{4}^{2-}\right)$, MSA $\left(\mathrm{CH}_{3} \mathrm{SO}_{3}^{-}\right)$ and oxalate were determined from the polycarbonate substrates using ion chromatographs (Dionex ICS-3000). The samples were extracted with $3 \mathrm{ml}$ of deionised water (Milli$\mathrm{Q}$, Millipore Gradient A10). The anions were analysed using a $4 \mathrm{~mm}$ i.d. $\times 250 \mathrm{~mm}$ length AS- 11 analytical column, a $4 \mathrm{~mm}$ i.d. $\times 50 \mathrm{~mm}$ length AG-11 guard column, ASRS ul-
Table 1. Hygroscopic growth factors of ammonium sulphate determined in H-TDMA calibrations.

\begin{tabular}{lc}
\hline Size $[\mathrm{nm}]$ & HGF \\
\hline 90 & $1.71 \pm 0.02$ \\
50 & $1.68 \pm 0.02$ \\
25 & $1.64 \pm 0.01$ \\
10 & $1.58 \pm 0.02$ \\
\hline
\end{tabular}

tra II suppressors and $\mathrm{KOH}$-eluent. The cations were analysed using a $4 \mathrm{~mm}$ i.d. $\times 250 \mathrm{~mm}$ length CS-12A analytical column, a $4 \mathrm{~mm}$ i.d. $\times 50 \mathrm{~mm}$ length CG-12A guard column, a $4 \mathrm{~mm}$ CSRS-ULTRA II suppressor and methanesulphonic acid eluent. The uncertainty of the ion chromatograph analysis is of the order of $10-15 \%$ for all analysed ions and the quantification limit for major ions was $2.5 \mathrm{ng} \mathrm{ml}^{-1}$. The blank samples, one for each analysed sample, were handled similarly and subtracted from the final presented results.

To compare with the aerosol physical measurements, the chemical mass balance was calculated for the smallest $(\leq 1 \mu \mathrm{m})$ impactor stages. Details of the analytical procedure are presented by Teinilä et al. (2000). The degree of neutralisation of the sulphuric acid with the ammonia was calculated based on $\mathrm{NH}_{4}^{+} / \mathrm{nss}-\mathrm{SO}_{4}^{2-}$ equivalent molar ratio. If the ratio was $\leq 1$, the aerosol was considered to be composed of ammonium bisulphate $\left(\left(\mathrm{NH}_{4}\right) \mathrm{HSO}_{4}\right)$ and sulphuric acid $\left(\mathrm{H}_{2} \mathrm{SO}_{4}\right)$, while with the ratio $\geq 2$ the aerosol was assumed to be ammonium sulphate $\left(\left(\mathrm{NH}_{4}\right)_{2} \mathrm{SO}_{4}\right)$ with some excess ammonia. In between the aerosol was considered as a mixture of $\left(\mathrm{NH}_{4}\right)_{2} \mathrm{SO}_{4}$ and $\left(\mathrm{NH}_{4}\right) \mathrm{HSO}_{4}$. The sea salt mass concentration was calculated as $\mathrm{Cl}^{-}+1.45 \cdot \mathrm{Na}^{+}$(Bates et al., 2001; Quinn et al., 2001; Virkkula et al., 2006b).

Organic and elemental carbon (OC and EC) samples of below $1 \mu \mathrm{m}$ particles were collected using two quartz fiber filters (Whatman Q-MA $47 \mathrm{~mm}$ ) placed in series in a filter cassette system (Gelman Sciences). Prior to the sampling, the quartz filters were cleaned at $550^{\circ} \mathrm{C}$ for six hours. In order to collect the submicrometre particle size fraction of PM only (aerodynamic particle diameter $<1 \mu \mathrm{m}, \mathrm{PM}_{1}$ ), the four upper stages (8-11) of the Berner low pressure impactor (BLPI) were installed prior to the filter to remove supermicrometre particles. The cut-size of the preimpactor $\left(D_{50}\right)$ is determined by the lowest stage, the others are used to divide the PM loading to several stages and to ensure removal of particles well above the lowest cut-size. The nominal $D_{50}$ value for stage 8 is $2 \mu \mathrm{m}$ with a flow rate of $24.5 \mathrm{~L} \mathrm{~min}^{-1}$, but since the flow rate of the BLPI was increased to $80 \mathrm{~L} \mathrm{~min}^{-1}$, the $D_{50}$ value for the stage 8 decreased to $1 \mu \mathrm{m}$. Calculation was based on the theory presented by Rader and Marple (1985) assuming that the flow is incompressible and the Stokes number is 0.24 .

A $1.0 \mathrm{~cm}^{2}$ piece was cut from the quartz filter for the analysis. The operation principle of the thermal-optical-analyser 
is shortly following: $\mathrm{OC}$ is volatilised at four subsequent temperature steps in pure helium (He) atmosphere after which the EC is determined in a mixture of oxygen $\left(\mathrm{O}_{2}\right)$ and helium at two temperature steps. Optical correction is applied for the separation of pyrolysed OC from EC. The temperature program used was similar to the EUSAAR_1 program (Cavalli et al., 2010). In total 13 blank samples were collected, and their concentrations were subtracted from the presented results. The uncertainty of the $\mathrm{OC}$ and $\mathrm{EC}$ results was estimated to be $20 \%$.

The water-soluble organic carbon (WSOC) was analysed by the total-organic carbon analyser TOC- $\mathrm{V}_{\mathrm{CPH}}$ from Shimadzu. The high sensitive catalyst was used to increase the sensitivity of the method. The non-purgeable organic carbon method (NPOC) used in the TOC analyser has been described in detail by Timonen et al. (2008). The preparation of a sample for the analysis was following: a $2 \mathrm{~cm}^{2}$ piece was cut from the $\mathrm{PM}_{1}$ quartz filter, submerged into $15 \mathrm{ml}$ of deionised water and rotated for $15 \mathrm{~min}$ prior to the analysis. The estimated error of the WSOC results is $15 \%$ for atmospheric concentrations $<2 \mu \mathrm{g} \mathrm{m}^{-3}$ and $10 \%$ for concentrations $>2 \mu \mathrm{g} \mathrm{m}^{-3}$.

SDI-impactor and OC/EC sampling system were mounted outside and the filters were stored in cold to prevent volatilisation of organic material. Thus, the cut-sizes are particle ambient diameters. Samples were collected for $48 \mathrm{~h}$ each within two to three days, depending on the wind direction. If the wind blew from the polluted sector $\left(200^{\circ}-275^{\circ}\right)$, the sector control switched off the sample collection.

\subsubsection{Particle and ion size distributions}

A twin-Differential Mobility Particle Sizer (DMPS) measured particle number size distributions in a size range of 3-1000 $\mathrm{nm}$ with a $10 \mathrm{~min}$ time resolution. The twin-DMPS consisted of two DMPS systems that were operated in parallel. A short Hauke-type Differential Mobility Analyser (DMA) (Knutson and Whitby, 1975; Winklmayr et al., 1991) of length $10.9 \mathrm{~cm}$ classified smaller particles $(3-25 \mathrm{~nm})$ in 10 separate sections according to their electrical mobility. Sheath flow was operated in closed-loop (Jokinen and Mäkelä, 1997). The sample and sheath flow rates were 4 and 20 LPM, respectively, and a calculation time of $45 \mathrm{~s}$ per channel was used. The particles were detected by a TSI condensation particle counter (CPC) model 3025 (Stolzenburg and McMurry, 1991). A Hauke-type DMA of length $28.5 \mathrm{~nm}$ classified the bigger $(10-950 \mathrm{~nm})$ particles in $30 \mathrm{sec}-$ tions. The sample and sheath (closed-loop) flow rates were 1 and 5 LPM, respectively, and the calculation time per channel was $6 \mathrm{~s}$. Bigger particles were detected with a TSI model 3010 CPC (Quant et al., 1992). The twin-DMPS system was used in a $\mathrm{PM}_{1}$ inlet with a total line length of $4 \mathrm{~m}$. The inlet top extended $2 \mathrm{~m}$ above the roof. A neutraliser (Ni-63, $370 \mathrm{MBq}$ ) was used to gain steady-state charge distribution of the particles. DMPS size ranges overlapped between 10 and $25 \mathrm{~nm}$ to ensure the similarity and quality of the measurements. In the inversion the particle diffusional losses in the DMPS were taken into account. Losses inside the CPCs and DMAs were measured after the campaign while diffusional sampleline losses were approximated based on the flow rates. It is possible that diffusional losses were slightly underestimated, as the concentrations in the first channel of the DMPS were low even during nucleation events. Thus, reliable DMPS data was considered to start at $4 \mathrm{~nm}$ size. In order to assure the quality of the DMPS data, the total particle number concentration $>10 \mathrm{~nm}$ was additionally measured with a TSI 3007 condensation particle counter.

The Air Ion Spectrometer (AIS), manufactured by AIREL Ltd., Estonia, classifies the air ions according to their electrical mobility (Asmi et al., 2009; Mirme et al., 2007). The AIS consists of two cylindrically symmetrical mobility analysers, one for positive and one for negative ions. Both analysers are operated in parallel. The inlet of the AIS was a copper tube with an outer diameter of $35 \mathrm{~mm}$ and a length $0.5 \mathrm{~m}$. The inlet was led through the ARL wall at the height of about $2 \mathrm{~m}$ above the ground. The AIS measured the air ion mobility distributions over a mobility range of $0.0013-3.16 \mathrm{~cm}^{2} \mathrm{~V}^{-1} \mathrm{~s}^{-1}$. This corresponds to a diameter range of $0.8-42 \mathrm{~nm}$ in normal temperature and pressure. As a result a number mobility (and size) distribution of positive and negative ions, divided into 28 mobility (and size) sections was achieved with a $5 \mathrm{~min}$ resolution.

\subsubsection{Supplementary instrumentation}

Weather parameters: temperature, pressure, relative humidity, global radiation, wind speed and wind direction, outside were recorded automatically with a year-round operating Milos-500 station located next to the ARL.

\section{Results}

\subsection{Meteorological conditions, origin of air masses and variation of aerosol particle total number and vol- ume over the whole measuring period}

The meteorological parameters: temperature, pressure, global radiation and wind speed, and their variation during the period of measurements (Fig. 2) give an overview of the weather conditions at the Aboa. Measured temperatures were typical of the summer season, varying between 0 and $-10^{\circ} \mathrm{C}$. Relative humidity varied in a range $30-100 \%$. The $\mathrm{RH}$ directly affects the particle physical form in the atmosphere. At these humidities it is unlikely that ammonium salts would crystallise but will retain their hygroscopic humid form. The tendency of the particles to retain their liquid form is even stronger for complex internal aerosol mixtures including organics (Marcolli et al., 2004). The sun stayed above the horizon throughout the day, but the amount of incoming global radiation had a distinct diurnal cycle 


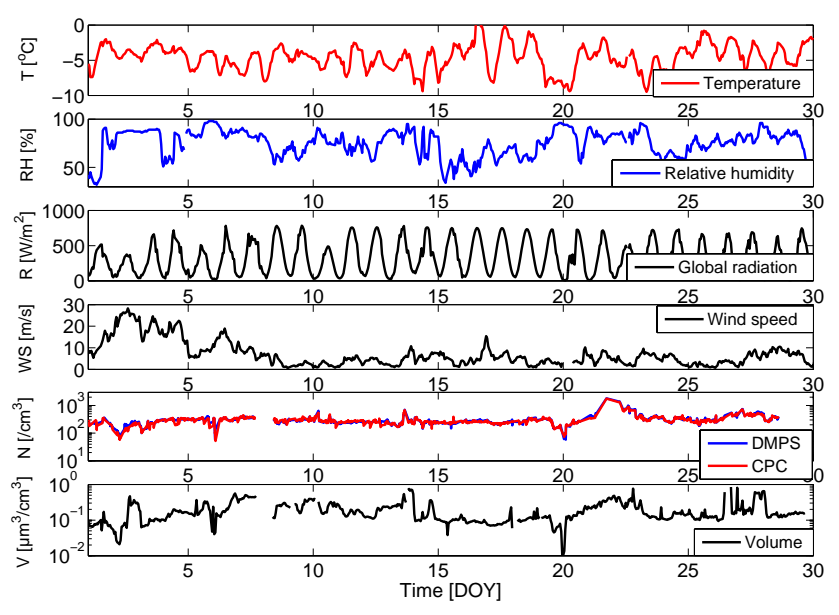

Fig. 2. Weather parameters and aerosol total number and volume concentrations measured at Aboa. Panels present temperature, relative humidity, global radiation, wind speed, particle total number and particle total volume in January 2007 from top to bottom, respectively. Both the intergrated number concentration from the DMPS data and the total number measured with CPC are presented. The volume concentration is calculated from the DMPS data.

following the solar zenith angle. Thus, the radiation values were high with the maxima at around midday (solar time). On sunny days maximum solar radiation was on the order of $800 \mathrm{~W} \mathrm{~m}^{-2}$. Cloud cover reduced the incoming radiation as for example on 2 January when the daily radiation maximum was only on the order of $400 \mathrm{~W} \mathrm{~m}^{-2}$. High solar radiation values and low RH values are shown to be favourable conditions for new particle formation (Hamed et al., 2007). Wind speed was high in the beginning of the measurement period but decreased to below $10 \mathrm{~m} \mathrm{~s}^{-1}$ after 7 January. High wind speeds intensify the vertical mixing and are seen to lead into formation of $<10 \mathrm{~nm}$ intermediate size ions at Aboa (Virkkula et al., 2007).

Particle total number and volume concentrations (Fig. 2) determined from DMPS data (sizes $<1 \mu \mathrm{m}$ ) in January 2007 were on the order of, or slighly lower, than previously measured at Aboa (Koponen et al., 2003; Virkkula et al., 2006a). The total number concentration varied from 50 to $3000 \mathrm{~cm}^{-3}$ giving the average and median values of 374 and $289^{-3}$, respectively. The integrated total number concentration from the DMPS agreed well with the number measured by the CPC alone. The new particle formation events are visible in the data as increased concentrations, especially on 20 and 21 January. The total volume concentration was on average $0.2 \mu \mathrm{m}^{3} \mathrm{~cm}^{-3}$. Underestimation of the volume was possible due to the relatively long sample line $(4 \mathrm{~m})$ leading to gravitational losses and low statistics of the measurements of the larger sized particles.

The origin of the air masses gives indications of the particle sources and sinks and was used to study the history of the particles. The possible particle sources in Antarctica include primary and secondary marine emissions, secondary particle formation in the troposphere, long-range transport of tropospheric particles and downward transport of stratospheric particles particularly following the break-up of polar vortex in spring. Previously, the secondary particle formation in the Antarctic troposphere has been thought to be the most significant source of sub-micrometre particles in Antarctica although there is a discussion on the importance of the different vapour sources (O’Dowd et al., 1997; Park et al., 2004; Shaw, 1988).

Air mass back trajectories were calculated with the NOAA/HYSPLIT (Hybrid Single Particle Lagrangian Integrated Trajectory Model, Draxler and Rolph, 2003; Rolph, 2003) model $120 \mathrm{~h}$ backwards every six hours for the heights of 10,500 and $1000 \mathrm{~m}$. The trajectories for the three heights showed similar history and were examined as a function of their latest contact with the ocean (Fig. 3). The model results suggest air masses of recent marine influence before 11 January, and on 13 and 23 January. In contrast, between 18 and 22 January, and on 24 January, the air masses travelled above the continent for at least 5 days backwards. Roughly the period of January 2007 can be divided into 3 parts: recent marine (days: 1-13 and 23), continental (days: 18-22) and mixed (days: 14-17 and 24-28).

Another way to examine the aerosol history was based on the measured data. Since the DMS oxidation is the only known source of the methanesulphonic acid (MSA), the relative mass contribution of MSA can be used as an indicator of marine influences. We calculated the MSA to nss- $\mathrm{SO}_{4}^{2-}$ total mass ratio derived from SDI-samples (Fig. 4). Typically in Antarctica the ratio extends from around 0.1 in central Antarctica to close to 1.0 in the Antarctic peninsula and the Southern Ocean (e.g. Legrand et al., 1992). At Aboa in summer season, average ratio of 0.28 and 0.39 was observed by Kerminen et al. (2000) in sub- and supermicrometre ranges, respectively. By comparing Figs. 3 and 4 we observed that in general the ratio was higher in marine air masses, thus coinciding with the trajectory analysis. However, the sample collected between 18 and 21 January showed a ratio as high as 0.4 , thus contradicting the modelled continental origin. It should be kept in mind that both methods include large uncertainties and they are vulnerable to different sources of errors. Therefore, no firm conclusions can be drawn based on individual trajectories. Both the ratio MSA/nss-SO ${ }_{4}^{2-}$ and the trajectories must be examined in particle source analysis and considered as indicatives of the general trends in air mass movements.

\subsection{Hygroscopic growth factors}

Throughout the measurement period the humidified distribution was one-modal, which indicated an internal mixture of the particles. Particle hygroscopic growth factors (HGF) during the period, total of 18 days, were high (Fig. 5). The 


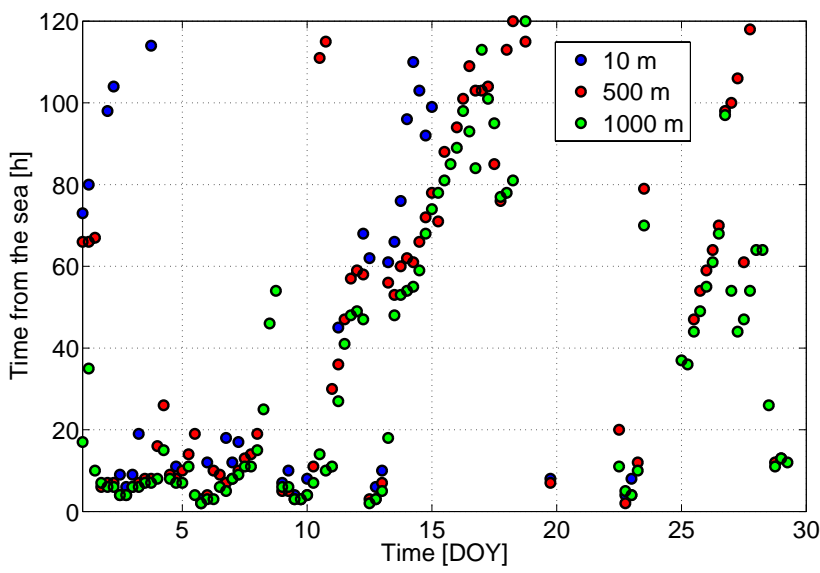

Fig. 3. Time of propagation (in hours) over the continent since last contact with the ocean calculated for trajectories arriving at Aboa at 10 (blue circles), 500 (red circles) and 1000 (green circles) m heights. Small number therefore corresponds to recent marine influence. Trajectories were calculated $120 \mathrm{~h}$ backwards every six hours. If the air mass spent the last $120 \mathrm{~h}$ over the continent, no circle was plotted.

average $\mathrm{HGF}$ of $90 \mathrm{~nm}$ particles at $90 \%$ was 1.75 thus exceeding the HGF of ammonium sulphate (which was 1.71, Table 1). The average hygroscopic growth factors of 50, 25 and $10 \mathrm{~nm}$ particles were $1.67,1.63$ and 1.49 , respectively. They were on the order of ammonium sulphate particle hygroscopic growth factors. Some variation in HGF values with time was also observed. This variation showed no definite diurnal cycle with the exception of $25 \mathrm{~nm}$ size, where on average, slightly increased values were observed in daytime.

The HGF values detected in this study are similar as measured previously in marine environments (e.g. Massling et al., 2007; Tomlinson et al., 2007). Swietlicki et al. (2008) summarise various HGF measurements around the world and discuss the composition of the marine "more hygroscopic" particles. They suggest three alternatives: partly neutralised DMS-derived sulphate, aged sea salt with inorganics and sodium sulphate, sea salt mixed with inorganics and organics, or a combination of these. These all can be considered as possible cases also in this study.

As discussed in previous section, meteorology affects the particles. We examined the role of meteorology with a linear regression model and calculated the correlation of measured meteorological parameters and air mass origin travel time from the ocean with the hygroscopic growth factors. The resulting $R^{2}$ values and their statistical significance are presented in Table 2. As expected, none of the meteorological variables alone can explain a large fraction of the measured variation in HGF values. Yet some connections were found. At 50 and $90 \mathrm{~nm}$ sizes the low HGF values were connected with the high relative humidity $\left(R^{2}=0.23\right.$ and 0.18$)$, high absolute air humidity $\left(R^{2}=0.31\right.$ and 0.20$)$ and to some extent

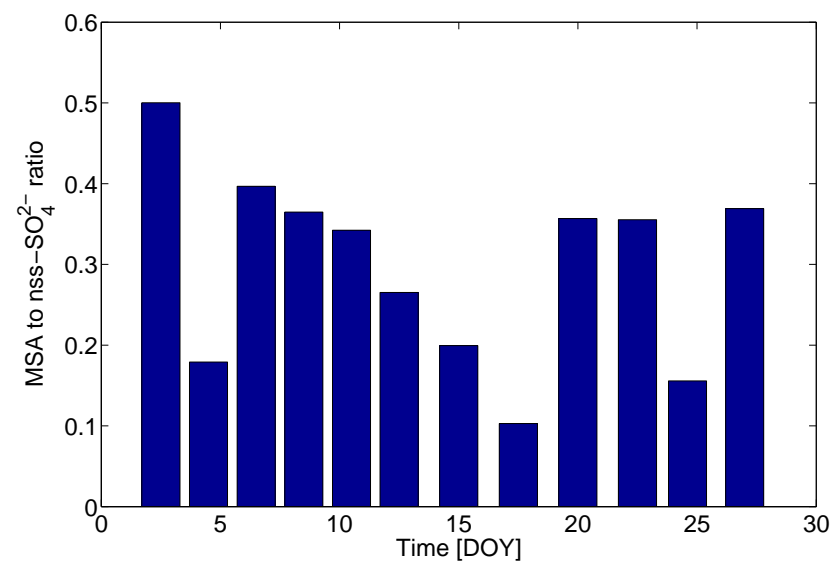

Fig. 4. Ratio of MSA [ $\mathrm{ng} \mathrm{m}^{-3}$ ] to nss-sulphate $\left[\mathrm{ng} \mathrm{m}^{-3}\right]$ in a size range of $0.045-20 \mu \mathrm{m}$ at Aboa, January 2007.

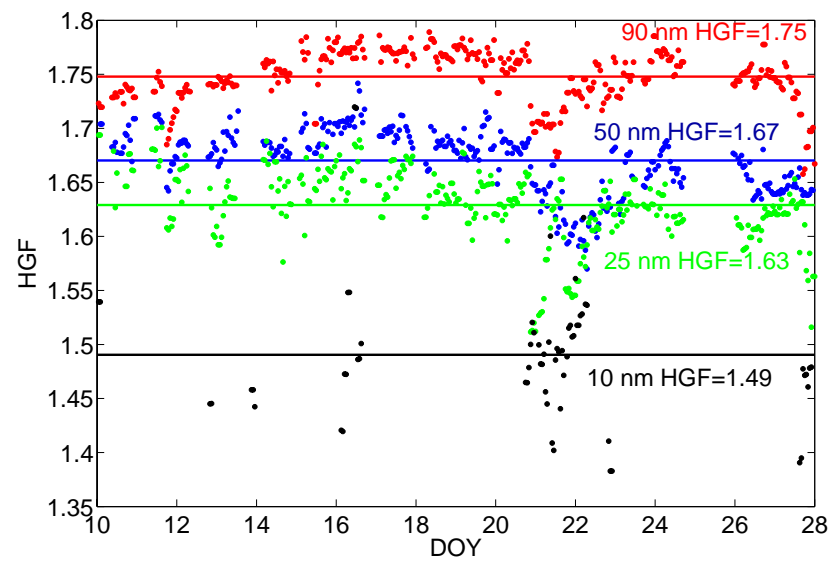

Fig. 5. Hygroscopic growth factors (HGF) of 90, 50, 25 and $10 \mathrm{~nm}$ particles as a function of time presented in red, blue, green and black dots, respectively, measured in January 2007 at Aboa. The lines present the average HGF values during the measurement period.

$\left(R^{2}=0.11\right.$ and 0.08 ) also with the air mass recent contact with the ocean. Recent contact with the ocean possibly has a coupling with the RH and humidity. Thus, moist (marine) air was found to decrease 50 and $90 \mathrm{~nm}$ particle hygroscopicity. Increased hygroscopic growth factors of $25 \mathrm{~nm}$ particles were also connected with low RH and humidity but not with the travel time from the ocean. This is believed to be explained by the fresh origin of the smaller sized particles in comparison with the larger sizes, which have been influenced by the air mass for a longer time. Larger particles additionally contain a bigger fraction of cloud processed aerosol particles. No definite connections could be found between $10 \mathrm{~nm}$ HGF values and weather, mainly because of the lack of HGF data for $10 \mathrm{~nm}$ particles. Additionally, correlation of HGF with solar radiation and temperature was tested but appeared to be 
Table 2. Correlation between wind speed (WS), relative humidity $(\mathrm{RH})$, global radiation $(R)$, temperature $(T)$, absolute humidity of the air (Hum) and trajectory travel time from the ocean $(\Delta t)$, and hygroscopic growth factors of 90, 50, 25 and $10 \mathrm{~nm}$ particles presented with calculated linear regression coefficient $\left(R^{2}\right)$ values. The $\Delta$ t values were calculated only for the trajectories which had been in connection with the ocean during the past five days. In brackets it is marked if the correlation is positive $(+)$ or negative $(-)$. An ${ }^{*}$ marks those correlations which were found to be statistically not significant ( $\mathrm{p}$-value $>0.05$ ).

\begin{tabular}{lllllll}
\hline Size $[\mathrm{nm}]$ & WS & RH & $R$ & $T$ & Hum & $\Delta t[\mathrm{~h}]$ \\
\hline 90 & $0.02(-)$ & $0.23(-)$ & $0.01(+)$ & $0.01(-)^{*}$ & $0.31(-)$ & $0.11(+)$ \\
50 & $0.02(-)$ & $0.18(-)$ & $0.03(+)$ & $0.00(-)^{*}$ & $0.20(-)$ & $0.08(+)$ \\
25 & $0.02(-)$ & $0.20(-)$ & $0.12(+)$ & $0.01(+)^{*}$ & $0.15(-)$ & $0.04(+)$ \\
10 & $0.01(-)^{*}$ & $0.05(-)^{*}$ & $0.01(+)^{*}$ & $0.01(+)^{*}$ & $0.06(-)$ & $0.12(+)^{*}$ \\
\hline
\end{tabular}

mostly non-existing. Only increased radiation seemed to increase the growth factors of $25 \mathrm{~nm}$ nucleation mode particles $\left(R^{2}=0.12\right)$, as could be expected based on a diurnal cycle of the $25 \mathrm{~nm}$ HGF values. This indicates a possible role of photochemistry for the freshly born secondary particle chemical composition.

The effect of RH and moisture on particle HGF could be due to 1) recent marine connection of the aerosol, 2) decreased source of condensing hygroscopic vapours through diminished gas-phase oxidation chemistry and increased vapour sink, or 3) different chemical reactions taking part in dry and moist aerosols.

1) The majority of Antarctic boundary layer $<1 \mu \mathrm{m}$ particles in summer compose most likely of sulphates of marine origin (Bigg et al., 1984; Gras, 1983; Ito, 1989; O'Dowd et al., 1997; Shaw, 1988) possibly together with some organics (Kawamura et al., 1996; Virkkula et al., 2006c). If the decreased hygroscopicity is due to the vicinity of the particle source (ocean) this could refer to the aging effect of the aerosol particles containing organics (Buchholz et al., 2009). Another option would be a gradual neutralisation of sulphuric acid with ammonia to form ammonium bisulphate, letovicite $\left(\left(\mathrm{NH}_{4}\right)_{3} \mathrm{H}\left(\mathrm{SO}_{4}\right)_{2}\right)$ and ammonium sulphate particles. O'Dowd et al. (1997) observed that Antarctic particles in marine air masses were more neutralised than particles in polar air masses, which implies that the Southern Ocean is the source of ammonia in Antarctica. This leads to higher hygroscopicity of the polar (continental) air mass particles, as the sulphate particle hygroscopicity decreases with the degree of ammonia neutralisation.

2) Increased RH, which further increases the particle surface area, leads to an enhanced sink of condensable vapours. Hamed et al. (2009) studied the concentration of gas phase sulphuric acid as a function of $\mathrm{RH}$ and observed a decreasing trend. They speculated that RH might have a similar effect on condensable organics. Both the suppression of source through increased RH and cloudiness, and enhancement of sink through increased particle surface area, and possibly water droplets, decrease the vapour source, which can further affect the particle chemical composition.

3) The third option is difficult to predict as the interference of water vapour for several inorganic and especially organic gas-phase chemical reactions is unknown. Additionally the particle chemistry, and furthermore hygroscopic properties, are affected by aqueous phase reactions taking place in liquid particles (e.g. Kane et al., 2001; Volkamer et al., 2009). Findings by Buchholz et al. (2009) suggest that secondary organics generated in sunny conditions are more hygroscopic and also more $\mathrm{CCN}$ active than those generated under cloudy conditions. Additionally Buchholz et al. (2009) observed that increased organic aerosol hygroscopicity with aging was enhanced in sunny conditions. If we assume that higher RH predicts cloudiness, this could partly explain our results. However, if we only consider the water content of the air without the cloudiness, Poulain et al. (2010) observed that secondary organic aerosol hygroscopicity increases with increasing water vapour mixing ratio.

To conclude, organic species heterogeneous and gas phase chemical reactions and aging of secondary organic aerosol in sunny conditions could affect the increased HGF values with decreasing RH and water content, assuming they indicate the vicinity of the marine source and decreased cloudiness. Also the degree of neutralisation of sulphuric acid might depend on the air mass origin and affect the hygroscopicity. Humid marine air masses, containing larger amounts of neutralised sulphate particles and less aged organics would thus lead to lower particle hygroscopicity.

A factor we found to affect the HGF variations was the relative humidity in the first DMA (Fig. 6). The HGF decreased with both increasing DMA1 RH and increasing time. If the HGF actually decreases with the DMA1 RH, this could suggest substances which do not exhibit deliquescence, such as some organics, MSA or sulphuric acid. However, the correlation is not well-defined and might also be a secondary effect of other influences, most probably the connection of sample air RH with the outdoor air RH. This correlation was 


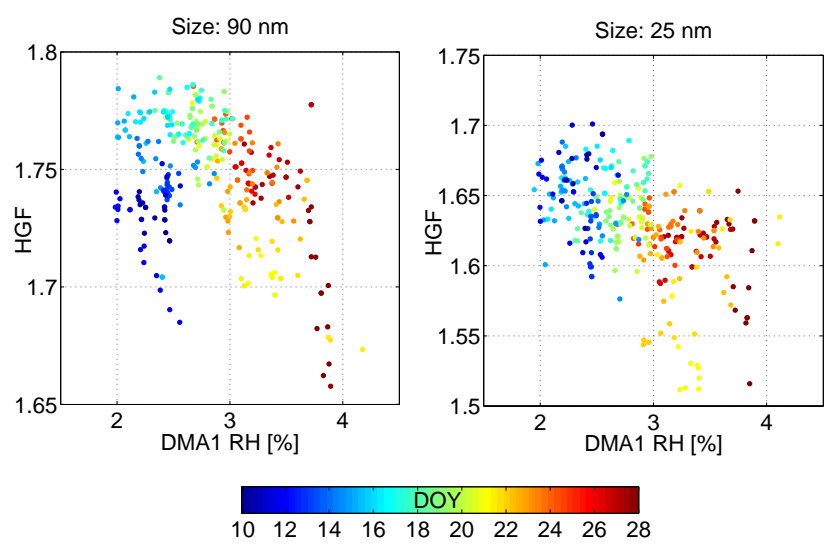

Fig. 6. Hygroscopic growth factors (HGF) of $90 \mathrm{~nm}$ (left figure) and $25 \mathrm{~nm}$ (right figure) particles as a function of the dry DMA1 RH. Additionally, the time (DOY January 2007) is presented with colour.

discussed above. Additionally, in the beginning of the period on 10-12 January the HGF values of $90 \mathrm{~nm}$ particles were low compared to the $25 \mathrm{~nm}$ HGF. Probably there were differences in the chemical composition between these sizes either as a consequence of separate sources, aging effect on particle chemistry or changes caused by cloud processing of larger sized particles.

To give an idea on the modal characteristic of the aerosols during our measurements, the particle number size distributions were grouped into three clusters. The clustering was done for normalised size distributions to find the differences in aerosol modal features. A matlab routine, where variance within the cluster was minimised and between the clusters was maximised, was used. The average size distributions in each cluster are presented in Fig. 7 and their couplings to particle hygroscopicity and air mass origin are presented in Table 3. The most predominant size distribution contained a strong Aitken mode and weaker nucleation and accumulation modes. The average total number concentration in this cluster was $309 \mathrm{~cm}^{-3}$ and the particles at all four sizes were very hygroscopic (Table 3). This size distibution type occured during both marine and continental air masses. The second most common size distribution type was characterised by a dominant accumulation mode and was prevailing during marine transported air masses. Compared with the predominant cluster type, a decrease in $90 \mathrm{~nm}$ particle hygroscopicity was observed. This could indicate the effect of cloud prosessing on marine accumulation mode particles leading to decreased hygroscopicity. The third cluster type was the most rare and comprised of a dominant nucleation mode. Continental air masses and decreased hygroscopicity of all particle sizes were observed to be characteristics of this cluster. Average number concentration in this cluster was the highest, being $1353 \mathrm{~cm}^{-3}$. To summarise, the cluster analysis ex-
Table 3. Variables (VAR) of particle total number $\left(N_{\text {tot }}\right)$, hygroscopic growth factors (HGF) and air mass origin corresponding to particle number size distributions grouped into three clusters $(\mathrm{C} 1$, $\mathrm{C} 2, \mathrm{C} 3$ ) presented in Fig. 7. Average and standard deviation of total particle number $\left[\mathrm{cm}^{-3}\right]$ and $\mathrm{HGF}$ of $90,50,25$ and $10 \mathrm{~nm}$ particles are presented for each cluster type. Additionally, the influence of marine, mixed and continental air masses are shown in [\%]. The air masses were devided based on the lowest $(10 \mathrm{~m})$ trajectory propagation time from the ocean using boundaries $<24 \mathrm{~h}$ (marine), 24-72 h (mixed), and $>72 \mathrm{~h}$ (continental).

\begin{tabular}{lrrr}
\hline VAR & C1 & C2 & C3 \\
\hline Ntot & $1350 \pm 890$ & $310 \pm 150$ & $290 \pm 80$ \\
HGF90 & $1.72 \pm 0.03$ & $1.76 \pm 0.02$ & $1.73 \pm 0.02$ \\
HGF50 & $1.63 \pm 0.03$ & $1.68 \pm 0.03$ & $1.68 \pm 0.02$ \\
HGF25 & $1.58 \pm 0.05$ & $1.64 \pm 0.02$ & $1.64 \pm 0.04$ \\
HGF10 & $1.50 \pm 0.04$ & $1.50 \pm 0.10$ & $1.47 \pm 0.05$ \\
Marine & 19 & 35 & 48 \\
Mixed & 11 & 18 & 34 \\
Cont. & 69 & 47 & 18 \\
\hline
\end{tabular}

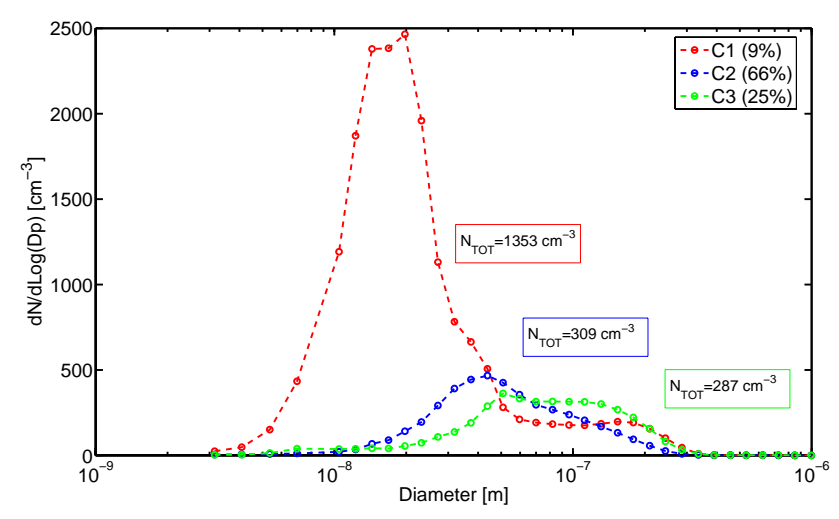

Fig. 7. The average particle number size distributions, resulting from grouping the data into three distinguishable internally similar clusters. The numbers in coloured boxes present the average total number concentration in each of the clusters while the legend present the prevalence of each cluster type as percents.

plains the differences occasionally observed between hygroscopic behaviour of different particle modes might be related to marine origin and cloud prosessing of aged accumulation mode aerosol. Additionally, decreased hygroscopicity was connected with the secondary new particle formation.

\subsection{Particle formation and growth}

The detected new particle formation events were classified according to Yli-Juuti et al. (2009). Compared to previous years (Virkkula et al., 2007; Koponen et al., 2003) the number of events was lower and from DMPS data, only three class I events could be observed (Table 4). With such a 
Table 4. New particle formation event classification between 29 December 2006-29 January 2007. The numbers refer to number of days of the total of 32 days. All types were not classified (n.c.) from DMPS data.

\begin{tabular}{lrrr}
\hline Event Class & DMPS & AIS $_{\text {NEG }}$ & AIS $_{\text {POS }}$ \\
\hline I & 3 & 2 & 2 \\
II & 3 & 3 & 1 \\
Apple & n.c. & 2 & 1 \\
Hump & n.c. & 1 & 0 \\
Wind/snow & n.c. & 6 & 0 \\
Mixed & n.c. & 3 & 3 \\
Non-event & 18 & 13 & 11 \\
Undefined & 5 & 2 & 2 \\
Bad data & 3 & 0 & 12 \\
\hline
\end{tabular}

low statistics, we were not able to reliably track the principal differences in weather patterns between nucleation and non-nucleation days. Particle formation was detected in both marine and continental air masses. All together, formation events were detected on $21 \%$ of the classified days. Additionally, in the beginning of January when wind speeds were high (Fig. 2) many wind initiated events were observed. These types of events at Aboa were first reported by Virkkula et al. (2007). Classifications of positive and negative ion formation events were congruent with each others on those days when data from both polarities existed.

Growth rates were calculated for class I and II events and for different size ranges separately, when possible. The calculation method was similar as presented by Dal Maso et al. (2005). A log-normal mode was fitted to each particle size spectrum. The growth rate was then calculated by fitting a linear line to the peaks of the fitted modes as a function of time. This method was unsuccessful for the smallest $(<4 \mathrm{~nm})$ particles when the shape of the particle mode was not well defined. Thus, for the smallest sizes, the method presented by Hirsikko et al. (2005) was used, where for each size one normal mode was fitted and the modal maximum value was used for linear fitting. In most of the event cases, only a growing mode of $>10 \mathrm{~nm}$ particles was observed. These particles grew at a rate $1.3-2.5 \mathrm{~nm} \mathrm{~h}^{-1}$, and the differences between particle and ion growth rates were small (Table 5). The 4-10 nm particle growth rates could be analysed for three events and on those cases, their growth rates were similar to larger, $10-20 \mathrm{~nm}$, particle growth rates. However, with only a few event cases, no further conclusions on the size dependence of the growth can be made. For reference, Virkkula et al. (2007) observed higher growth rates for larger than for smaller ions at Aboa. From our data, the only day when the growth rates could be calculated for 2-4 nm ions was 21 January. Thus, this day was selected for further studies.

On 21 January, the new particle formation event started with an increase of the $1.5-3 \mathrm{~nm}$ negative ions simulta-
Table 5. Total particle (DMPS), negative ion $\left(\mathrm{AIS}_{\mathrm{NEG}}\right)$ and positive ion $\left(\mathrm{AIS}_{\mathrm{POS}}\right)$ growth rates at different size sections: $2-4 \mathrm{~nm}$, 4-10 $\mathrm{nm}$ and $10-20 \mathrm{~nm}$ for class I and II events (see Table 4). The range of all the determined growth rates is presented, if the value was calculated for many event days. Note that in some events, only the growth rate of the largest particles could be determined and the ranges of growth rates are therefore not directly comparable between different size sections.

\begin{tabular}{lrrr}
\hline $\begin{array}{l}\text { Size } \\
\text { range }[\mathrm{nm}]\end{array}$ & $\begin{array}{r}\text { DMPS } \\
{\left[\mathrm{nm} \mathrm{h}^{-1}\right]}\end{array}$ & $\begin{array}{r}\text { AIS } \\
{\left[\mathrm{nm} \mathrm{h}^{-1}\right]}\end{array}$ & $\begin{array}{r}\text { AIS } \\
{\left[\mathrm{nm} \mathrm{h}^{-1}\right]}\end{array}$ \\
\hline $2-4$ & - & 1.5 & - \\
$4-10$ & $0.8-2.1$ & 2.3 & 1.7 \\
$10-20$ & $1.3-2.5$ & $1.2-2.4$ & $1.5-2.6$ \\
\hline
\end{tabular}

neously as the negative cluster ion concentration declined (Fig. 8). This effect was only observed in negative polarity, possibly as an indication of sign preference of the nucleation (Laakso et al., 2004; Winkler et al., 2008; Kurtén et al., 2009; Nadykto et al., 2008). Similarly, growth of negative cluster ions to $>1.5 \mathrm{~nm}$ sizes was as well observed in four (out of the five) events, but these events were too weak to be analysed in detail. Two examples of the observed charge preference in nucleation are presented in Fig. 9. Additionally, in a paper by Virkkula et al. (2007) (and Fig. 7 therein) similar behaviour can be observed. Thus, the initial growth of negative ions seems to be characteristic to Antarctic new particle formation events.

On the strongest event day, 21 January, formation of 1.5$3 \mathrm{~nm}$ negative ions lasted for several hours and at the same time, the particles grew to larger sizes. The growing mode was detected in positive cluster spectra at $4 \mathrm{~nm}$ size, as an indication of aerosol neutralisation (Fig. 9). The growth rate of negative $2-4 \mathrm{~nm}$ ions was $1.5 \mathrm{~nm} \mathrm{~h}^{-1}$. The growth rate of 4 $10 \mathrm{~nm}$ positive and negative ions were 1.7 and $2.3 \mathrm{~nm} \mathrm{~h}^{-1}$, respectively. Simultaneously measured neutral particle growth rate was only $1.3 \mathrm{~nm} \mathrm{~h}^{-1}$. A possible reason for the higher ion growth rates could be the gradual neutralisation process towards the steady-state charge distribution which can artificially increase them.

The negative ions appeared to have a significant role in the initial phase of the formation process on 21 January. Recently, the relative importance of ion-induced, or ion-mediated, nucleation compared to the atmospheric neutral particle nucleation has been under intensive discussion (Kazil et al., 2008). Thus, we calculated the total $4 \mathrm{~nm}$ particle formation rate $\left(J_{4}\right)$ from the DMPS data, using measured 4-10 nm particle concentrations, and compared it with the negative $2 \mathrm{~nm}$ ion formation rate $\left(J_{2 \mathrm{NEG}}\right)$, calculated from the AIS data in a size range of $2-3 \mathrm{~nm}$. Formation rates for particles and ions were calculated with methods presented by Kulmala et al. (2001) and Kulmala et al. (2007). At the time of the event, the $J_{4}$ was $1.0 \pm 0.1 \mathrm{~cm}^{-3} \mathrm{~s}^{-1}$ while the 


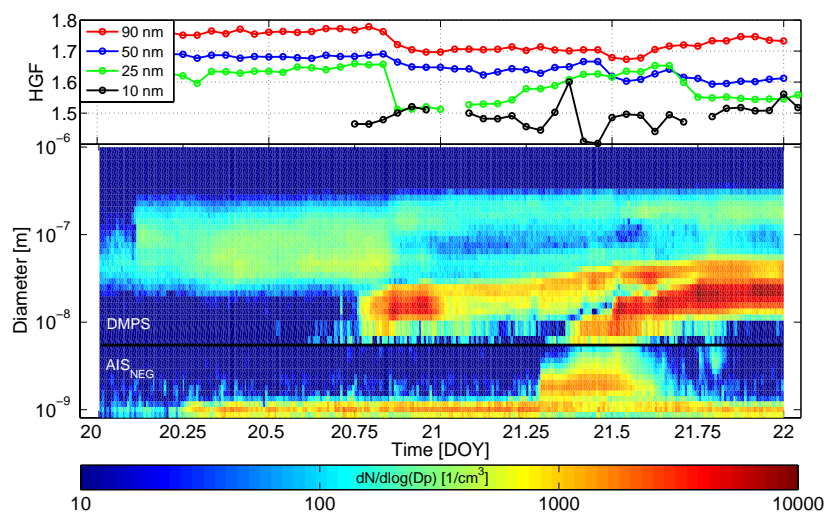

Fig. 8. In the upper panel, the measured HGF values for the four particle sizes as a function of time on 20 and 21 January, 2007. In the lower panel, the aerosol particle and negative ion number size distribution as a function of time measured on 20 and 21 January, 2007. The y-axis shows the size ranging from $0.8 \mathrm{~nm}$ up to $1 \mu \mathrm{m}$. Colour presents the concentration. Particle size distributions above $5 \mathrm{~nm}$ size are measured with the DMPS and below that are the distributions of negative ions measured with the AIS.

$J_{2 \mathrm{NEG}}$ was $0.3 \pm 0.1 \mathrm{~cm}^{-3} \mathrm{~s}^{-1}$. From $J_{4}$ we could further calculate the $2 \mathrm{~nm}$ particle formation rate $\left(J_{2}\right)$ with the method presented by Kerminen and Kulmala (2002). Using values $0.1 \mathrm{~cm}^{2} \mathrm{~s}^{-1}, 1000 \mathrm{~kg} \mathrm{~m}^{-3}$ and $1.3 \mathrm{~nm} \mathrm{~h}^{-1}$ for the diffusion coefficient, particle density and particle growth rate, the total $2 \mathrm{~nm}$ particle formation rate, $J_{2}$, became $1.3 \pm 0.1 \mathrm{~cm}^{-3} \mathrm{~s}^{-1}$. The calculated particle formation rate was thus on the order of those detected in the boreal forest region (e.g. Dal Maso et al., 2005).

In addition to the direct ion-induced particle formation, a fraction of neutral particle formation can be explained by recombination of negative and positive clusters and their nucleation. Therefore, also the formation rate of $2-3 \mathrm{~nm}$ recombination clusters was calculated using the same method as in Manninen et al. (2009). The formation rate of recombination clusters, $J_{\mathrm{rec}}$, was $0.10 \pm 0.04 \mathrm{~cm}^{-3} \mathrm{~s}^{-1}$. As positive ion formation in the size range of $2-3 \mathrm{~nm}$ was not observed, total ion-mediated particle formation rate was thus calculated as a sum of negative ion and recombination cluster formation rates and was on the order of $0.4 \mathrm{~cm}^{-3} \mathrm{~s}^{-1}$. Compared to the total particle formation rate, $1.3 \mathrm{~cm}^{-3} \mathrm{~s}^{-1}$, the ion-mediated contribution was thus on the order of $30 \%$. Even though, at least in this one event case, the neutral particles seem to dominate the formation process in Antarctica, the contribution of ions to particle formation was higher than on average in boreal forest region (Manninen et al., 2009).

\subsection{Closer look at the hygroscopic growth factors during new particle formation}

In addition, we examined the recently nucleated particle hygroscopicity. The most pronounced decrease in HGF oc-
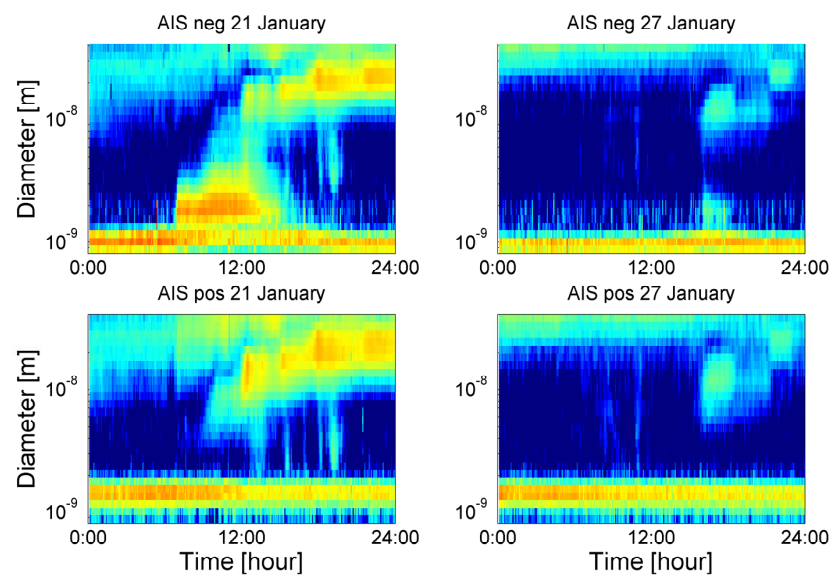

Fig. 9. Negative (upper panels) and positive (lower panels) air ion number size distributions on 21 and 27 January, 2007.

curred on 20-21 January (Fig. 5). Those two days included the strongest particle formation events of the period (Fig. 8). The simultaneous air ion distribution spectrum shows that the formation and growth of small 1-2 nm ions on $21 \mathrm{Jan}-$ uary occurred in the measured air mass. On 20 January we could only identify the growing mode $>10 \mathrm{~nm}$, but not the initial phase of the formation event. These two events had a definite effect on the particle hygroscopicity. The $25 \mathrm{~nm}$ particle HGF values declined rapidly at the time when the growing mode reached this size. Slightly lower HGF values were also measured for 50 and $90 \mathrm{~nm}$ particles, possibly as a consequence of particle dynamics and/or different air mass origin. As the particles grew and aged, their hygroscopicity increased. Both the fact that formation at $1-2 \mathrm{~nm}$ sizes was observed at the measurement site and that the HGF values of these particles approached those determined on nonnucleation days imply that the origin of summer Antarctic aerosol can be the Antarctic boundary layer. Even though the hygroscopicity of recently nucleated particles was lower, it increased within some hours to the previously measured level.

Reduced hygroscopicity of freshly nucleated particles could indicate an important role of organic vapours for the growth, while organics are generally less hygroscopic than sulphate. Oxidation of the organic aerosol further increases the hygroscopicity which is detected as an increase of HGF with time. This hypothesis is as well supported with the previous results from Aboa by Virkkula et al. (2006a) where a decline in the refractive index was observed during nucleation events as a possible indication of the biological particles.

The air mass origin based on backward trajectory analysis was continental during the event days, 20-21 January. As the air masses turned from continental to marine on 22 January, the size distribution changed rapidly and the growing particle 
mode disappeared. However, high MSA to nss- $\mathrm{SO}_{4}^{2-}$ ratio on the event days implied marine influences. Thus, the origin of the nucleated particles remains partly unclear.

\subsection{Particle volatility}

The V-TDMA measurements were made during one day only. However, they revealed some more interesting features of the aerosols and can thus be not excluded. Interestingly, that these highly hygroscopic particles were also highly volatile (Fig. 10). Major volatilisation occurred between temperatures 50 and $60^{\circ} \mathrm{C}$. At $100^{\circ} \mathrm{C} 90$ and $50 \mathrm{~nm}$ particle diameters had decreased about $40 \%$ corresponding to a major volume loss. Diameter of $25 \mathrm{~nm}$ particle decreased about $20 \%$ between 40 and $100^{\circ} \mathrm{C}$. Differences in volatilisation between particle sizes can be understood by different sources and composition of the particles and by the enhanced neutralisation of smaller sized sulphate particles (Biskos et al., 2009). This would, however, indicate that the most of the particle mass is sulphuric acid, only partly neutralised by ammonia. Indeed there are observations of sulphuric acid particles in summer Antarctic boundary layer, e.g. by Bigg et al. (1984); O'Dowd et al. (1997), which is confirmed also by modelling studies (Adams et al., 1999). Particles of similar hygroscopicity and volatility as here were also recently measured in south-eastern Pacific by Tomlinson et al. (2007). They measured hygroscopicities of particles to be on the order of, or even higher, than those of ammonium bisulphate. Additionally, they showed that $200 \mathrm{~nm}$ particles were more volatile than $50 \mathrm{~nm}$ particles, while at $150{ }^{\circ} \mathrm{C} 200 \mathrm{~nm}$ particle diameter decreased on average by more than $30 \%$.

\subsection{Size dependence of particle ionic composition}

Even though each particle of specific composition has a particular hygroscopicity and volatility behaviour, their measurements alone can not directly specify the particle composition. Chemical analysis of size-segregated particle mass can assist in determining the particle composition with the downside that the short-term changes are lost. The ionic composition was analysed from SDI filter masses, measured with 2-3 day resolution. Mass concentrations of determined ionic species and their modal distribution (at Table 6) resembled those previously measured at Aboa (Teinilä et al., 2000; Virkkula et al., 2006b). The most abundant ionic species in the smallest sizes were nss-sulphate, ammonium and MSA (Fig. 11). Most mass was concentrated on stages 4 and 5 (diameters $230-590 \mathrm{~nm}$ ), which were dominated by nsssulphate. At larger sizes the mass fraction of sodium, nitrate and chloride increased, as an indication of sea salt particles. Small amounts of oxalate were also observed. In larger particles small amounts of magnesium, potassium and calcium were found which suggested primary emitted soil particles but could also be related to primary sea spray aerosol. Previous results of the particle chemical composition at Aboa

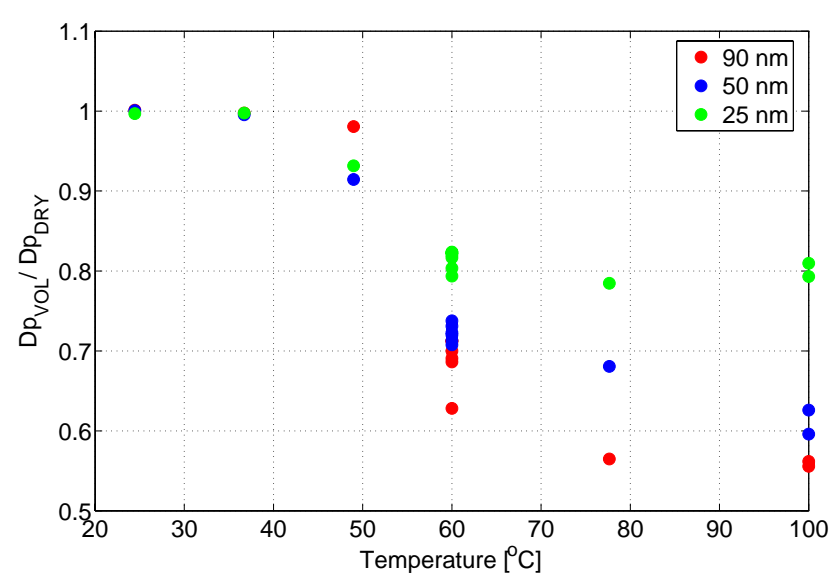

Fig. 10. Diameter of volatilised, initially 90,50 and $25 \mathrm{~nm}$ sized non-volatilised, dry particles as a function of volatilisation temperature presented in red, blue and green dots, respectively, measured on 29 January, 2007.

and in the surroundings have been presented by Virkkula et al. (2006b) and Teinilä et al. (2000) where more information on the typical ionic composition of different particle modes can be found. In this work, we focused on the most abundant chemical species observed in the $<1 \mu \mathrm{m}$ particle mode. Thus, the chemical mass balance was only calculated for the smallest particle sizes, following the mixing rules described in Sect. 2.2.2.

The chemical analysis revealed that Aitken mode particles were more neutralised compared to the accumulation mode particles, as expected (Biskos et al., 2009). On average, in the 12 samples collected, approximately $40 \%$ of the stage 1 mass was ammonium bisulphate, $20 \%$ was ammonium sulphate, $30 \%$ was sulphuric acid and $10 \%$ was MSA. The fraction of sulphuric acid and MSA was higher in the next two stages (stages 2-3). The mass concentration of the sulphate species $\left(\left(\mathrm{H}_{2} \mathrm{SO}_{4}\right),\left(\left(\mathrm{NH}_{4}\right) \mathrm{HSO}_{4}\right),\left(\left(\mathrm{NH}_{4}\right)_{2} \mathrm{SO}_{4}\right)\right), \mathrm{MSA}$ and sea salt in particles between 45 and $231 \mathrm{~nm}$ in size (aerodynamic wet-diameter) was calculated together to represent the composition of the Aitken and lower accumulation mode and thus, the composition of the largest particles measured with the H-TDMA. Their composition was dominated by sulphuric acid (Fig. 12).

\subsection{Organic carbon in sub-micrometre particles}

Relative abundance of sulphur compounds showed only minor changes with time. Next, we will consider the variation of the total sub-micrometre mass and include organics to the picture.

Measurements by Virkkula et al. (2006b) and Kerminen et al. (2000) suggest that in samples collected at Aboa an important amount of mass remains unexplained by the analysed ions in both sub- and super-micrometre ranges. They 
Table 6. Average concentrations $\left[\mathrm{ng} \mathrm{m}^{-3}\right.$ ] and standard deviations of SDI measured ions and organic carbon and water-soluble organic carbon at ranges: $<1 \mu \mathrm{m},>1 \mu \mathrm{m}$ and total in 12 collected samples. OC and WSOC were only measured below $1 \mu \mathrm{m}$ and backup filter masses are substracted.

\begin{tabular}{lrrr}
\hline Species & $<1 \mu$ mean \pm std & $>1 \mu$ m mean \pm std & Total mean \pm std \\
\hline${\mathrm{nss}-\mathrm{SO}_{4}^{2-}}_{\mathrm{Cl}^{-}}^{226.6 \pm 102.9}$ & $28.1 \pm 12.6$ & $254.8 \pm 111.4$ \\
$\mathrm{NO}_{3}^{-}$ & $1.4 \pm 2.0$ & $18.2 \pm 16.2$ & $19.5 \pm 17.4$ \\
$\mathrm{MSA}^{-}$ & $2.4 \pm 2.5$ & $16.0 \pm 10.4$ & $18.5 \pm 12.3$ \\
$\mathrm{Ox}^{2-}$ & $71.7 \pm 44.8$ & $10.2 \pm 7.9$ & $81.9 \pm 51.1$ \\
$\mathrm{Na}^{+}$ & $0.47 \pm 0.16$ & $0.41 \pm 0.23$ & $0.88 \pm 0.34$ \\
$\mathrm{NH}_{4}^{+}$ & $11.5 \pm 7.8$ & $24.9 \pm 16.0$ & $36.4 \pm 22.2$ \\
$\mathrm{nss}^{+}$ & $6.6 \pm 2.8$ & $0.9 \pm 0.6$ & $7.6 \pm 3.2$ \\
$\mathrm{nss}^{+} \mathrm{Mg}^{2+}$ & $0.10 \pm 0.09$ & $0.20 \pm 0.44$ & $0.31 \pm 0.46$ \\
$\mathrm{nss-Ca}$ & $0.06 \pm 0.14$ & $0.00 \pm 0.00$ & $0.06 \pm 0.14$ \\
$\mathrm{OC}$ & $2.8 \pm 2.1$ & $1.2 \pm 0.6$ & $4.0 \pm 2.4$ \\
$\mathrm{WSOC}$ & $45 \pm 32$ & - & - \\
\hline
\end{tabular}

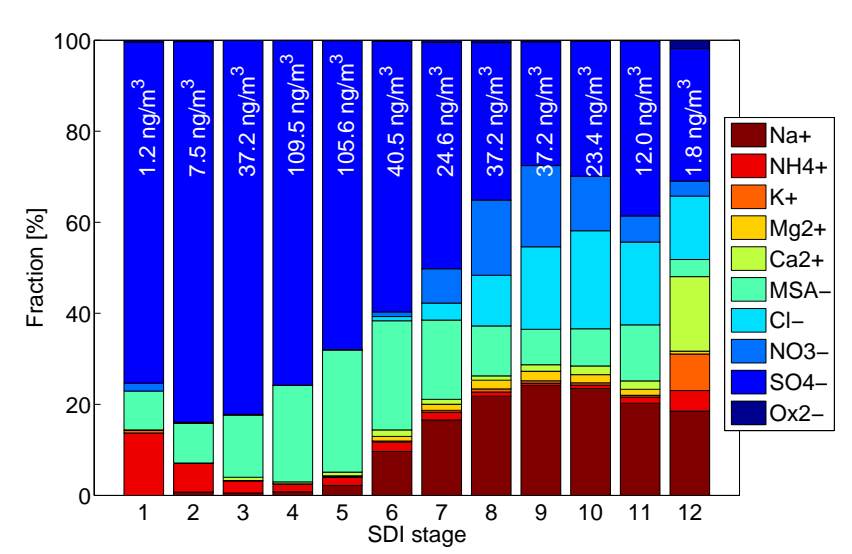

Fig. 11. Average relative masses of ten most abundant ions measured with a 12-stage SDI impactor in January 2007 at Aboa. The SDI-stages 1-12 cover a aerodynamic size range from $45 \mathrm{~nm}$ up to $20 \mu \mathrm{m}$. Each colour corresponds to an analysed ion which are: $\mathrm{Na}^{+}$, $\mathrm{NH}_{4}^{+}, \mathrm{K}^{+}, \mathrm{Mg}^{2+}, \mathrm{Ca}^{2+}, \mathrm{MSA}^{-}\left(\mathrm{CH}_{3} \mathrm{SO}_{3}^{-}\right), \mathrm{Cl}^{-}, \mathrm{NO}_{3}^{-}, \mathrm{SO}_{4}^{2-}$ and Oxalate ${ }^{-}\left(\mathrm{C}_{2} \mathrm{O}_{4}^{2-}\right.$.) Additionally, the average sum of the ion mass concentrations at different stages are given in figure.

suggest that organics might be an explanation for the missing mass. Additionally, the volatility measurements made here suggested that there are more volatile species than the sulphuric acid concentration alone would explain. Already previous studies have implied the existence of organic species in Antarctica (Saxena, 1983; Saxena et al., 1985). Kawamura et al. (1996) measured water-soluble organic carbon in aerosols at the Syowa station and their results indicated a marine origin of the organics and further transformation by photochemical oxidation. Additionally, Virkkula et al. (2006c) measured organic carbon concentrations during a cruise from South Africa to Antarctica and their results showed small

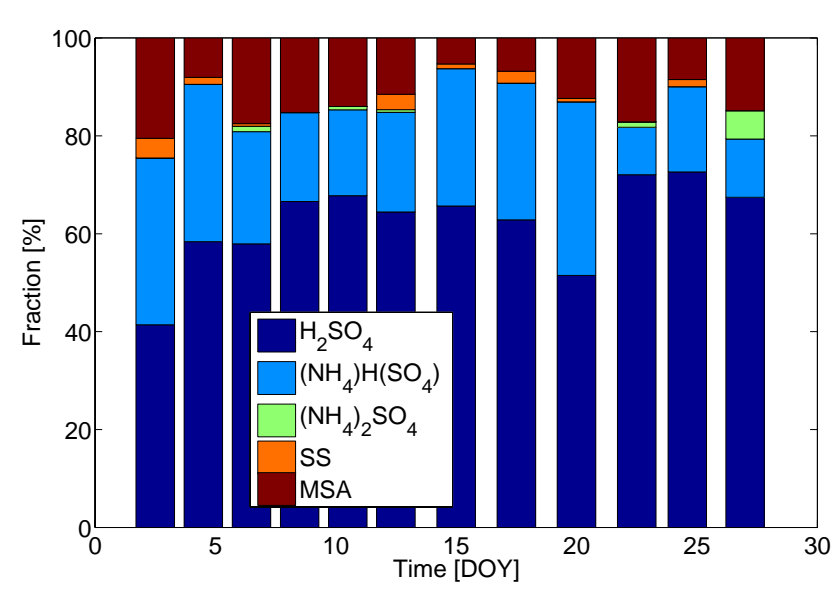

Fig. 12. Relative mass composition of five components in aerosol particles as a function of time measured in January 2007 at Aboa. The fractions of massed are calculated using the summed masses of the three lowest SDI-stages corresponding to a size range from $45 \mathrm{~nm}$ up to $231 \mathrm{~nm}$. Each colour corresponds to a chemical component which are: $\mathrm{H}_{2} \mathrm{SO}_{4},\left(\mathrm{NH}_{4}\right) \mathrm{HSO}_{4},\left(\mathrm{NH}_{4}\right)_{2} \mathrm{SO}_{4}$, Sea Salt (SS) and MSA.

amounts of organic carbon present also on the coast of the Antarctica. It is well known that ocean is a source of primary and secondary organic aerosols (e.g. Gantt et al., 2009; Gershey, 1983; O’Dowd et al., 2004; Spracklen et al., 2008). The vicinity of the ocean does therefore suggest that organics, also other than MSA, could be found in the aerosols at the Aboa. Additionally, the finding of oxalate from SDI samples supports this.

Water-soluble and total organic carbon concentrations were measured in sub-micrometre particles and the insoluble organic carbon fraction was estimated by subtracting the 
WSOC from the total OC (Table 6). Using a factor of 3.2 for the water-soluble organic carbon and a factor of 1.3 for the water-insoluble organic carbon, as suggested by Turpin and Lim (2001), we could determine the total mass of organic compounds (Fig. 13). However, it is not straightforward to measure organic carbon (Turpin et al., 2000). Besides the problems in determining the actual mass from the measured carbon, the mass of carbon in the aerosol phase is typically estimated by subtracting the backup filter from the front filter. This includes some uncertainties and to give an approximation of these uncertainties here, we made both lower and higher estimate for the organic mass (Fig. 13). In higher estimate the backup filter mass was not subtracted. The mass of the five most abundant ions measured with SDI-impactor in stages 1-7 $(<1 \mu \mathrm{m})$ and the mass of water-soluble and insoluble organic matter (WSOM and WINSOM) particles below $1 \mu \mathrm{m}$ in size were compared with the mass measured with the DMPS in the aerodynamic size range of $45 \mathrm{~nm}-1 \mu \mathrm{m}$. The organic carbon in MSA was subtracted from the measured organic carbon in WSOM.

DMPS and chemical mass balance calculations showed similar temporal behaviour of particle mass (Fig. 13). It appeared that organics explained most of the missing mass. Considering the lower organic estimate only, the fraction of organic matter (excluding MSA) in the total ionic mass was $2-46 \%$, with an average of $22 \%$. Probably the mass of organic substances lied somewhere between the lower and higher estimate as it was likely that DMPS slightly underestimated the total mass. The finding of an important fraction of organic matter in the aerosol phase can also nicely explain the temporal variations observed in H-TDMA data, which were discussed earlier.

\subsection{Hygroscopicity closure between chemistry and H-TDMA}

Even though we now know that there are organics in submicrometre range we do not know their exact contribution in different sizes. Thus, to make a closure from H-TDMA, VTDMA, size-segregated chemical ion and OC data, we need to use some rough estimates.

Literature values for hygroscopicity of $\mathrm{H}_{2} \mathrm{SO}_{4}$, $\left(\mathrm{NH}_{4}\right) \mathrm{HSO}_{4},\left(\mathrm{NH}_{4}\right)_{2} \mathrm{SO}_{4}$, Sea Salt (SS) and MSA can be found from various sources, (e.g. Johnson et al., 2004; Peng et al., 2001b; Peng and Chan, 2001a; Tang, 1996; Topping et al., 2005). We used values 1.6 for MSA, 2.3 for sea salt, 1.7 for ammonium sulphate, 1.8 for ammonium bisulphate, and 1.9 for sulphuric acid, to estimate the $45-230 \mathrm{~nm}$ particle hygroscopic growth factors at $90 \%$ based on the measured ionic species (Table 7). As the measured masses were small and sensitive to large errors, we used the sum of the three lowest SDI-stages (Fig. 12), corresponding to Aitken and lower accumulation mode sizes $(45-230 \mathrm{~nm})$, to estimate the HGF values. However, as the masses of nitrate and oxalate were small at this size range,
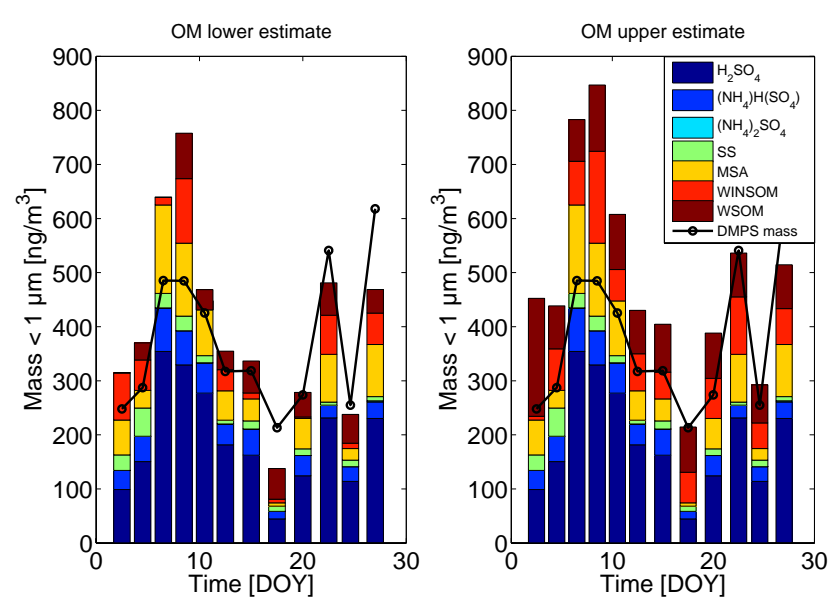

Fig. 13. Mass concentration of $\mathrm{PM}_{1}$ (aerodynamic diameter below $1 \mu \mathrm{m})$ as a function of time at Aboa in January 2007. Black line presents the mass calculated from the DMPS data assuming a density of $1.7 \mathrm{~g} \mathrm{~cm}^{-3}$. Coloured bars present the chemical components of the particles. Each colour corresponds to a chemical component which are: $\mathrm{H}_{2} \mathrm{SO}_{4},\left(\mathrm{NH}_{4}\right) \mathrm{HSO}_{4},\left(\mathrm{NH}_{4}\right)_{2} \mathrm{SO}_{4}$, Sea Salt (SS), MSA, Water-INSoluble Organic Matter (WINSOM) and Water-Soluble Organic Matter (WSOM). Factors 1.3 and 3.2 were used to convert from organic carbon (OC) to WINSON and WSOM, respectively. Left panel presents the lowest estimate for the OM (front filter backup) and right panel the highest estimate for the OM (front filter only). Organic material are determined from $\mathrm{PM}_{1}$ filter samples and others from SDI-impactor samples.

they were left out from the calculations. At the first estimate, the organics were excluded from the HGF calculations. In additional estimates, $30 \%$ and $20 \%$ of the organics were included to the total mass of the ions. The HGF values were calculated using the Zdanovskii, Stokes and Robinson (ZSR) mixing rule (Stokes and Robinson, 1966),

$\mathrm{GF}_{\text {mixed }}(\mathrm{RH})=\left(\sum_{i} v_{i} \cdot \mathrm{GF}_{i}(\mathrm{RH})^{3}\right)^{1 / 3}$

which assumes individual compounds, $i$, in a mixture take up water independently with respect to their volume fractions, $v_{i}$. Densities used to convert between mass and volume fractions are presented in Table 7. A density of $1400 \mathrm{~kg} \mathrm{~m}^{3}$ was estimated for organic matter based on literature values for dicarboxylic and multifunctional acids (Peng and Chan, 2001a).

The organic matter hygroscopic growth factor was difficult to estimate, as it varies largely between species (Kanakidou et al., 2005). For this reason, two different scenarios were added. First, we assumed a value of 1.4, which is relatively high for organic matter. This selection was based on measured HGF values for multifunctional and dicarboxylic acids (Peng et al., 2001b), and is in agreement with the values recently estimated for marine organics (Hersey et al., 2009). The assumption of dicarboxylic acids in Antarctic aerosol is 
Table 7. Density and HGF values used for different species to estimate their contribution to the measured $90 \mathrm{~nm}$ HGF values in Fig. 14.

\begin{tabular}{lrr}
\hline Species & $\rho\left[\mathrm{kg} / \mathrm{m}^{3}\right]$ & HGF \\
\hline $\mathrm{H}_{2} \mathrm{SO}_{4}$ & 1830 & 1.9 \\
$\left(\mathrm{NH}_{4}\right) \mathrm{HSO}_{4}$ & 1780 & 1.8 \\
$\left(\mathrm{NH}_{4}\right)_{2} \mathrm{SO}_{4}$ & 1769 & 1.7 \\
$\mathrm{SS}$ & 2165 & 2.3 \\
$\mathrm{MSA}$ & 1481 & 1.6 \\
$\mathrm{ORG}$ & 1400 & $1.4 / 1.2$ \\
\hline
\end{tabular}

supported by observations (Kawamura et al., 1996). Additionally, for some organic species the HGF values can be on the order of the ammonium sulphate HGF values (Fletcher et al., 2007) or even higher (Peng et al., 2001b). HGF similar to those of inorganic aerosols have been measured for inorganic-dicarboxylic acid aerosol mixtures (Wise et al., 2003). In second scenario, the fraction of organics and their HGF were decreased. A HGF value of 1.2 was used, as it has been observed to be generally representative for atmospheric organics in many environments (e.g. Gysel, 2007).

The growth factors estimated without the organics resulted in too high values (Fig. 14). In contrast, the calculated average $\mathrm{HGF}$ of 1.75 , matching the measured value, was obtained by adding $30 \%$ of organics with HGF of 1.4. However, similar decrease in hygroscopicity was also obtained by adding $20 \%$ of less hygroscopic organics with HGF of 1.2. This shows that some amount of organics are needed to explain the measured HGF of particles. The two additional scenarios of organic properties can be used to approximate the organic mass fraction. The temporal behaviour of the estimated HGF, which reflected the minor variations in relative chemical mass composition of the sulphates and MSA in the lowest SDI-stages, was close to the measured HGF (Fig. 14). The remaining discrepancies between modelled and measured HGF values are thought to be reasoned by variations in the organic mass fraction with time and its hygroscopic properties. This is well supported by the fact that the calculated HGF is overestimated in marine air masses (10 to 13 January) and underestimated in continental air masses (18 to 22 January) when using a constant organic HGF and volume fraction. Now, the observed behaviour of decreasing HGF with increasing RH can be explained by changes in sulphate chemistry, MSA volume fraction and organic aerosol hygroscopicity and/or volume fraction, as direct results from air mass travel time from the ocean. Additionally, the volume fraction of the sum of organics and sulphuric acid varied in a range 55-80\%. Assuming both of them were highly volatile, we could explain the measured volatile fractions of the particles.

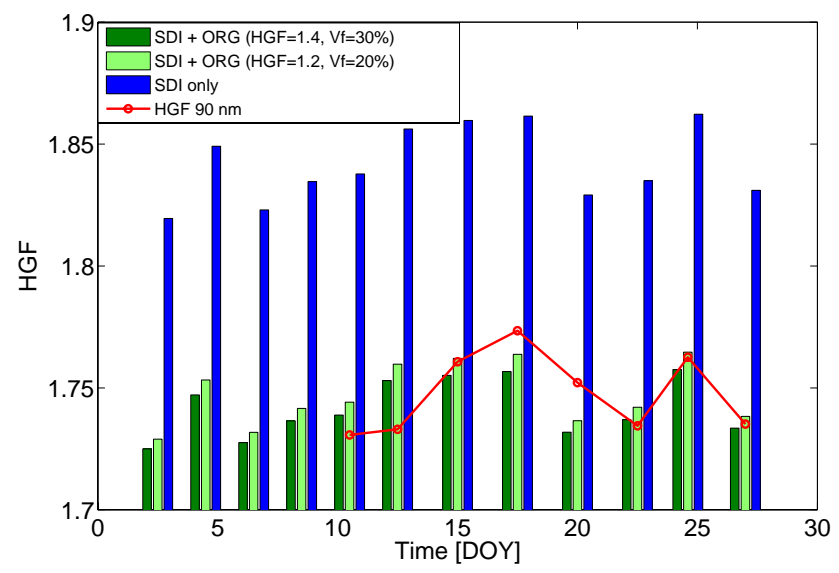

Fig. 14. Hygroscopic growth factor estimates based on HGF literature values of $\mathrm{H}_{2} \mathrm{SO}_{4},\left(\mathrm{NH}_{4}\right) \mathrm{HSO}_{4},\left(\mathrm{NH}_{4}\right)_{2} \mathrm{SO}_{4}$, Sea Salt (SS), MSA and organic species (ORG). The volume fractions (except ORG) were derived from the masses of SDI-impactor three lowest stages presented in Fig. 12. Estimations were done with (in green) and without (in blue) the additional organics. For additional organics two scenarios were tested. In the first scenario, $30 \%$ of organics (30\% addition to the total mass of inorganic species) with HGF of 1.4 were added (dark green) while in the second scenario $20 \%$ of organics with HGF of 1.2 were added. HGF and density values used in the chemical species HGF estimation are presented in Table 7.

\subsection{Discussion}

The comparison with chemical species and measured $90 \mathrm{~nm}$ HGF values was successful. However, relatively high HGF values were used for sulphuric acid and organic species. For sulphuric acid, the HGF value of 1.9 is justified with the fact that H-TDMA measurements were made between 2-4.5 and $90 \%$ RH while most of the earlier measurements are made between 10 and $90 \% \mathrm{RH}$, which affects the HGF of highly water-soluble sulphuric acid. The high HGF, 1.4, for organics could be explained by aging as the aerosol travels from the ocean to the measurement site. It is well known that organics can become more hygroscopic with time via oxidation processes. However, in our case, the aerosol was relatively hygroscopic and yet, at the same time, very volatile. There are some indications of organic species which do become both more hygroscopic and more volatile by aging (Asa-Awaku et al., 2009; Meyer et al., 2009; Poulain et al., 2010). However, as organics are highly variable species it is not straightforward to estimate their properties, and especially not in an environment so unique and practically missing all anthropogenic influences. Therefore, an additional scenario using an organic HGF of 1.2 being in closer agreement with numerous previous studies, was added. Also, what was not measured nor considered here was the role of amines. Amines have been observed in the particle phase (Barsanti et al., 2009). They can serve as bases for aminium salts and 
make a significant contribution to marine secondary organic aerosol mass (Facchini et al., 2008). Amines might explain a part of the organic species detected here. Their thermodynamic properties are, however, poorly known. Their effect on the particle characteristics, such as their hygroscopicity, is thus infeasible to estimate.

As particle CCN activation was not measured directly, only speculative conclusions can be made based on the measured data. High hygroscopicity implies highly CCN active aerosol. New particle formation events were plainly important for $\mathrm{CCN}$ production by increasing the total particle number. As shown by Kuang et al. (2009), the newly formed particles can make a significant contribution to the total $\mathrm{CCN}$ numbers. However, the rarity of the events complicated the further statistical analysis of the phenomenon. Even though the particle composition and hygroscopic properties at Aboa were partly characterised by sulphate species, the organics played an important role. Marine organics can influence particle hygroscopic (Hersey et al., 2009; Saxena et al., 1995) and CCN properties. Meskhidze and Nenes (2006) measured higher CCN concentrations in the Southern Ocean when over the bloom of phytoplankton. De Felice et al. (1997) connected the measured CCN concentrations in the Antarctic peninsula with the meteorological conditions, and they also speculate about the role of organics for the CCN. Additional $\mathrm{CCN}$ measurements should be made to confirm the conclusion of the highly $\mathrm{CCN}$ active Antarctic summer aerosol.

The biggest limitation of these measurements was the short time period. Particularly the volatility measurements should be interpreted with reservation. It seems likely that chemical composition and hygroscopic properties vary largely with season. Additionally, the distance from the open ocean can have a dramatic impact on the particle chemical composition, for example the degree of neutralisation of sulphuric acid as well as on the organic aerosol properties via the aging effect.

\section{Conclusions}

Our results suggest that nucleation, Aitken and accumulation mode aerosol particles at Aboa are both very hygroscopic (average HGF of 1.75 for $90 \mathrm{~nm}$ particles) and very volatile. High hygroscopicity is specific to sea environments only. The effect of meteorology on the particle hygroscopicity is small, though HGF values in moist and recently marine air masses are generally lower. The aerosol particle hygroscopic growth factors are enhanced in polar, continental air masses mainly for two reasons: 1) aging of marine originated organic aerosol increases and 2) MSA volume fraction decreases. In addition, the degree of sulphuric acid neutralisation with ammonia affects the HGF values. These results imply that the Southern Ocean controls the aerosols at Aboa being the most significant source of the particles and the condensing vapours, at least during summer season.
Particle hygroscopic properties imply that they are very $\mathrm{CCN}$ active. Chemical composition is mainly sulphuric acid, partly neutralised by ammonia, together with MSA and other organics. Approximately $20-30 \%$ of the $\leq 1 \mu \mathrm{m}$ aerosol mass in summer is of organic origin, other than MSA. However, the aerosol organic fraction can have large temporal and spatial variations. These, and the size dependency of the organic mass fraction would need further studies. The organic fraction can, together with sulphuric acid, explain the measured high volatility of the aerosol.

New particle formation events were detected on $21 \%$ of the classified days. A typical feature of the events is the preference of negative ions in the initial phase of the particle formation. One event day was analyser further and ion and total particle formation rates were calculated. The total $2 \mathrm{~nm}$ particle formation rate was $1.3 \pm 0.1 \mathrm{~cm}^{-3} \mathrm{~s}^{-1}$ and the maximum contribution from ion-mediated particle formation on that day was around $30 \%$. Growth of $<1.5 \mathrm{~nm}$ ions, as a first phase of new particle formation, was observed at the measurement site on 21 January. Direct detection of the growth of the smallest cluster ions indicates that nucleation in Antarctica can occur in the boundary layer and/or in the lower troposphere. In air masses of freshly nucleated particles the HGF values are decreased but will increase with time in subsequent particle growth. Thus, aging of the aerosol seems to increase the particle hygroscopicity. The variation of HGF values during new particle formation and growth can be explained by two factors: 1) increased organic aerosol contribution in the initial phase of particle formation and further organic aerosol heterogeneous oxidation and condensation, and 2) decreasing organic contribution in comparison to other condensing vapours following the growth of the nucleation mode. However, both cases suggest that organics, or other less hygroscopic species, participate in the particle growth process.

Acknowledgements. The authors want to acknowledge laboratory personnel in the University of Helsinki and in the Finnish Meteorological Institute. Especially Pasi Aalto, Erkki Siivola and Timo Mäkelä are acknowledged for their help in the instrumental field and in technical questions. Kimmo Teinilä is acknowledged for sharing his scientific expertise in aerosol chemistry. The logistical support of FINNARP is greatly acknowledged. This study was funded by the Academy of Finland (Finnish Antarctic Research Program, no. 2109980, "Dynamics, seasonal variation and chemistry of the Antarctic aerosol"). The financial support by the Academy of Finland Centre of Excellence program (project no. $1118615)$ is also gratefully acknowledged.

Edited by: K. Hämeri 


\section{References}

Adams, P. J., Seinfeld, J. H., and Koch, D. M.: Global concentrations of tropospheric sulfate, nitrate, and ammonium aerosol simulated in a general circulation model, J. Geophys. Res., 104, 13791-13823, 1999.

Asa-Awuku, A., Engelhart, G. J., Lee, B. H., Pandis, S. N., and Nenes, A.: Relating CCN activity, volatility, and droplet growth kinetics of -caryophyllene secondary organic aerosol, Atmos. Chem. Phys., 9, 795-812, doi:10.5194/acp-9-795-2009, 2009.

Asmi, E., Sipilä, M., Manninen, H. E., Vanhanen, J., Lehtipalo, K., Gagné, S., Neitola, K., Mirme, A., Mirme, S., Tamm, E., Uin, J., Komsaare, K., Attoui, M., and Kulmala, M.: Results of the first air ion spectrometer calibration and intercomparison workshop, Atmos. Chem. Phys., 9, 141-154, doi:10.5194/acp-9-141-2009, 2009.

Barsanti, K. C., McMurry, P. H., and Smith, J. N.: The potential contribution of organic salts to new particle growth, Atmos. Chem. Phys., 9, 2949-2957, doi:10.5194/acp-9-2949-2009, 2009.

Bates, T. S., Quinn, P. K., Coffman, D. J., Johnson, J. E., Miller, T. L., Coverts, D. S., Widensohler, A., Leinert, S., Nowak, A., and Neusüss, C.: Regional physical and chemical properties of the marine boundary layer aerosol across the Atlantic during Aerosol99: An overwiew, J. Geophys. Res., 106, 20767-20782, 2001.

Bellouin, N., Boucher, O., Haywood, J., and Reddy, M. S.: Global estimate of aerosol direct radiative forcing from satellite measurements, Nature, 438, 1138-1140, doi:10.1038/nature04348, 2005.

Bigg, E. K., Gras, J. L, and Evans, C.: Origin of Aitken particles in remote regions of the southern hemisphere, J. Atmos. Chem., 1, 203-214, 1984.

Bilde, M. and Svenningsson, B.: CCN activation of slightly soluble organics: the importance of small amounts of inorganic salt and particle phase, Tellus, 56B, 128-134, 2004.

Birch, M. E. and Cary, R. A.: Elemental carbon-based method for monitoring occupational exposures to particulate diesel exhaust, Aerosol Sci. Tech., 25, 221-241, 1996.

Biskos, G., Buseck, P. R., and Martin, S. T.: Hygroscopic growth of nucleation-mode acidic sulfate particles, J. Aerosol Sci., 40, 338-347, 2009.

Buchholz, A., Mentel, Th. F., Tillmann, R., Schlosser, E., Mildenberger, K., Clauss, T., Henning, S. Kiselev, A., and Stratmann, F.: Photochemical aging of secondary organic aerosols: effects on hygroscopic growth and CCN activation, Geophys. Res. Abstracts, 11, EGU2009-8288, 2009.

Cavalli, F., Viana, M., Yttri, K. E., Genberg, J., and Putaud, J.P.: Toward a standardised thermal-optical protocol for measuring atmospheric organic and elemental carbon: the EUSAAR protocol, Atmos. Meas. Tech., 3, 79-89, doi:10.5194/amt-3-79-2010, 2010.

Dal Maso, M., Kulmala, M., Riipinen, I., Wagner, R., Hussein, T., Aalto, P. P., and Lehtinen, K. E. J.: Formation and growth of fresh atmospheric aerosols: eight years of aerosol size distribution data from SMEAR II, Hyytil, Finland, Boreal Environ. Res., 10, 323336, 2005.

De Felice, T. P., Saxena, V. K., and Yo, S.: On the measurements of the cloud condensation nuclei at Palmer station, Antarctica, Atmos. Environ., 31, 4039-4044, 1997.
Draxler, R. R. and Rolph, G. D.: HYSPLIT (Hybrid Single-Particle Lagrangian Integrated Trajectory), Model access via NOAA ARL READY Website (http://www.arl.noaa.gov/ready/hysplit4. html), Silver Spring, MD: NOAA Air Resources Laboratory, 2003.

Ehn, M., Petäjä, T., Aufmhoff, H., Aalto, P., Hmeri, K., Arnold, F., Laaksonen, A., and Kulmala, M.: Hygroscopic properties of ultrafine aerosol particles in the boreal forest: diurnal variation, solubility and the influence of sulfuric acid, Atmos. Chem. Phys., 7, 211-222, doi:10.5194/acp-7-211-2007, 2007a.

Ehn, M., Petäjä, T., Birmili, W., Junninen, H., Aalto, P., and Kulmala, M.: Non-volatile residuals of newly formed atmospheric particles in the boreal forest, Atmos. Chem. Phys., 7, 677-684, doi:10.5194/acp-7-677-2007, 2007b.

Facchini, M. S., Decesari, S., Rinaldi, M., Carbone, C., Finessi, E., Mircea, M., Fuzzi, S., Moretti, F., Tagliavini, E., Ceburnis, D., and O'Dowd, C. D.: Important source of marine secondary organic aerosol from biogenic amines, Environ. Sci. Technol., 42, 9116-9121, doi:10.1021/es8018385, 2008.

Fletcher, C. A., Johnson, G. R., Ristovski, Z. D., and Harvey, M.: Hygroscopic and volatile properties of marine aerosol observed at Cape Grim during P2P campaign, Environ. Chem., 4, 162171, 2007.

Gantt, B., Meskhidze, N., and Kamykowski, D.: A new physically-based quantification of marine isoprene and primary organic aerosol emissions, Atmos. Chem. Phys., 9, 4915-4927, doi:10.5194/acp-9-4915-2009, 2009.

Gershey, R. M.: Characterization of seawater organic matter carried by bubble-fenerated aerosols, Limnol. Oceanogr., 28, 309-319, 1983.

Gras, J. L.: Ammonia and ammonium concentrations in the antarctic atmosphere, Atmos. Environ., 17, 815-818, 1983.

Gysel, M., Crosier, J., Topping, D. O., Whitehead, J. D., Bower, K. N., Cubison, M. J., Williams, P. I., Flynn, M. J., McFiggans, G. B., and Coe, H.: Closure study between chemical composition and hygroscopic growth of aerosol particles during TORCH2, Atmos. Chem. Phys., 7, 6131-6144, doi:10.5194/acp-7-61312007, 2007.

Gysel, M., McFiggans, G. B., and Coe, H.: Inversion of tandem differential mobility analyser (TDMA) measurements, Aerosol Sci., 40, 134-151, 2009.

Hamed, A., Joutsensaari, J., Mikkonen, S., Sogacheva, L., Dal Maso, M., Kulmala, M., Cavalli, F., Fuzzi, S., Facchini, M. C., Decesari, S., Mircea, M., Lehtinen, K. E. J., and Laaksonen, A.: Nucleation and growth of new particles in Po Valley, Italy, Atmos. Chem. Phys., 7, 355-376, doi:10.5194/acp-7-355-2007, 2007.

Hamed, A., Korhonen, H., Sihto, S.-L., Joutsensaari, J., Järvinen, H., Lehtinen, K. E. J., Kulmala, M., and Laaksonen, A.: Why does high relative humidity suppress continental nucleation events?, European Aerosol Conference 2009, Karlsruhe, Abstract T041A07.

Hersey, S. P., Sorooshian, A., Murphy, S. M., Flagan, R. C., and Seinfeld, J. H.: Aerosol hygroscopicity in the marine atmosphere: a closure study using high-time-resolution, multiple-RH DASHSP and size-resolved C-ToF-AMS data, Atmos. Chem. Phys., 9, 2543-2554, doi:10.5194/acp-9-2543-2009, 2009.

Hillamo, R., Allegrini, I., Sparapani, R., and Kerminen, V.-M: Mass size distributions and precursor gas concentrations of major inor- 
ganic ions in Antarctic aerosol, Int. J. Environ. Anal. Chem., 71, 353-372, 1998.

Hirsikko, A., Laakso, L., Hõrrak, U., Aalto, P. P., Kerminen, V.M., and Kulmala, M.: Annual and size dependent variation of growth rates and ion concentraions in boreal forest, Boreal Environ. Res., 10, 357-369, 2005.

Ito, T.: Antarctic submicron aerosols and long-range transport of pollutants, Ambio, 18, 34-41, 1989.

Johnson, G., Ristovski, Z., and Morawska, L.: Application of the VH-TDMA technique to coastal ambient aerosols, Geophys. Res. Lett., 31, L16105, doi:10.1029/2004GL020126, 2004.

Jokinen, V. and Mäkelä, J. M.: Closed-loop arrangement with critical orifice for DMA sheat/excess frow system, J. Aerosol Sci., 28, 643-648, 1997.

Kanakidou, M., Seinfeld, J. H., Pandis, S. N., Barnes, I., Dentener, F. J., Facchini, M. C., Van Dingenen, R., Ervens, B., Nenes, A., Nielsen, C. J., Swietlicki, E., Putaud, J. P., Balkanski, Y., Fuzzi, S., Horth, J., Moortgat, G. K., Winterhalter, R., Myhre, C. E. L., Tsigaridis, K., Vignati, E., Stephanou, E. G., and Wilson, J.: Organic aerosol and global climate modelling: a review, Atmos. Chem. Phys., 5, 1053-1123, doi:10.5194/acp-5-1053-2005, 2005.

Kane, S. M., Caloz, F., and Leu, M. T.: Heterogeneous uptake of gaseous $\mathrm{N}_{2} \mathrm{O}_{5}$ by $\left(\mathrm{NH}_{4}\right)_{2} \mathrm{SO}_{4}, \mathrm{NH}_{4} \mathrm{HSO}_{4}$, and $\mathrm{H}_{2} \mathrm{SO}_{4}$ aerosols, J. Phys. Chem. A, 105, 6465-6470, doi:10.1021/jp010490x, 2001.

Kawamura, K., Seméré, R., Imai, Y., Fujii, Y., and Hayashi, M.: Water soluble dicarboxylic acids and related compounds in Antarctic aerosols, J. Geophys. Res., 101, 18721-18728, 1996.

Kazil, J., Harrison, R. G., and Lovejoy, E. R.: Tropospheric new particle formation and the role of ions, Space Sci. Rev., 137, 241255, 2008.

Kerminen, V.-M.: The effects of particle chemical characteristics and atmosphere processes on particle hygroscopic properties, J. Aerosol Sci., 28, 121-132, 1997.

Kerminen, V.-M., Teinilä, K., and Hillamo, R.: Chemistry of seasalt particles in the summer Antarctic atmosphere, Atmos. Environ., 34, 2817-2825, 2000.

Kerminen, V.-M. and Kulmala, M.: Analytical formulae connecting the "real" and the "apparent" nucleation rate and the nuclei number concentration for atmospheric nucleation events, J. Aerosol Sci., 33, 609-622, 2002.

Knutson, E. O. and Whitby, K. T.: Aerosol classification by electric mobility: apparatus, theory and applications, J. Aerosol Sci., 6, 443-451, 1975.

Koponen, I. K., Virkkula, A., Hillamo, R., Kerminen, V.M., and Kulmala, M.: Number size distributions and concentrations of the continental summer aerosols in Queen Maud Land, Antarctica, J. Geophys. Res., 108, 4587-4597, doi:10.1029/2003JD003614, 2003.

Kuang, C., McMurry, P. H., and McCormick, A. V.: Determination of cloud condensation nuclei production from measured new particle formation events, Geophys. Res. Lett., 36, L09822, doi:10.1029/2009GL037584, 2009.

Kulmala, M., Toivonen, A., Mäkelä, J. M., and Laaksonen, A.: Analysis of the growth of nucleation mode particles observed in Boreal forest, Tellus, 50B, 449-462, 1998.

Kulmala, M., Dal Maso, M., Mäkelä, J. M., Pirjola, L., Väkevä, M., Aalto, P., Miikkulainen, P., Hämeri, K., and O’Dowd, C. D.:
On the formation, growth and composition of nucleation mode particles, Tellus, 53B, 479-490, 2001.

Kulmala, M., Vehkamäki, H., Petäjä, T., Dal Maso, M., Lauri, A., Kerminen, V.-M., Birmili, W, and McMurry, P. H.: Formation and growth rates of ultrafine atmospheric particles: a review of observations, J. Aerosol Sci., 35, 143-176, 2004.

Kulmala, M., Riipinen, I., Sipilä, M., Manninen, H. E., Petäjä, T., Junninen, H., Dal Maso, M., Mordas, G., Mirme, A., Vana, M., Hirsikko, A., Laakso, L., Harrison, R. M., Hanson, I., Leung, C., Lehtinen, K. E. J., and Kerminen, V.-M.: Toward direct measurement of atmospheric nucleation, Science, 5(318), 89-92, 2007.

Kurtén, T., Ortega, I. K., and Vehkamäki, H.: The sign preference in sulfuric aci d nucleation, J. Mol. Struct., 901, 169-173, 2009.

Laakso, L., Anttila, T., Lehtinen, K. E. J., Aalto, P. P., Kulmala, M., Hõrrak, U., Paatero, J., Hanke, M., and Arnold, F.: Kinetic nucleation and ions in boreal forest particle formation events, Atmos. Chem. Phys., 4, 2353-2366, doi:10.5194/acp-4-2353-2004, 2004.

Legrand, M., Feniet-Saigne, C., Saltzman, E. S., and Germain, C.: Spatial and temporal variations of methanesulfonic acid and non sea salt sulfate in antarctic ice, J. Atmos. Chem., 14, 245-260, 1992.

Maenhaut, W. R., Hillamo, R., Mäkelä, J., Jaffrezo, J.-L., Bergin, M. H., and Davidson, C. I.: A nec cascade impactor for aerosol sampling with subsequent PIXE analysis, Nucl. Instrum. Methods Phys. Res., Sect. B, 109/110, 482-487, 1996.

Manninen, H. E., Nieminen, T., Riipinen, I., Yli-Juuti, T., Gagné, S., Asmi, E., Aalto, P. P., Petäjä, T., Kerminen, V.-M., and Kulmala, M.: Charged and total particle formation and growth rates during EUCAARI 2007 campaign in Hyytiälä, Atmos. Chem. Phys., 9, 4077-4089, doi:10.5194/acp-9-4077-2009, 2009.

Marcolli, C., Luo, B., and Peter, T.: Mixing of the Organic Aerosol Fractions: Liquids as the Thermodynamically Stable Phases, J. Chem. Phys. A, 108(12), 2216-2224, 2004.

Martin, S. T., Hung, H.-M., Park, R. J., Jacob, D. J., Spurr, R. J. D., Chance, K. V., and Chin, M.: Effects of the physical state of tropospheric ammonium-sulfate-nitrate particles on global aerosol direct radiative forcing, Atmos. Chem. Phys., 4, 183-214, doi:10.5194/acp-4-183-2004, 2004.

Massling, A., Leinert, S., Wiedensohler, A., and Covert, D.: Hygroscopic growth of sub-micrometer and one-micrometer aerosol particles measured during ACE-Asia, Atmos. Chem. Phys., 7, 3249-3259, doi:10.5194/acp-7-3249-2007, 2007.

McFiggans, G., Artaxo, P., Baltensperger, U., Coe, H., Facchini, M. C., Feingold, G., Fuzzi, S., Gysel, M., Laaksonen, A., Lohmann, U., Mentel, T. F., Murphy, D. M., O’Dowd, C. D., Snider, J. R., and Weingartner, E.: The effect of physical and chemical aerosol properties on warm cloud droplet activation, Atmos. Chem. Phys., 6, 2593-2649, doi:10.5194/acp-6-2593-2006, 2006.

Meskhidze, N. and Nenes, A.: Phytoplankton and cloudiness in the Southern Ocean, Science, 314, 1419-1423, doi:10.1126/science.1131779, 2006.

Meyer, N. K., Duplissy, J., Gysel, M., Metzger, A., Dommen, J., Weingartner, E., Alfarra, M. R., Prevot, A. S. H., Fletcher, C., Good, N., McFiggans, G., Jonsson, Å. M., Hallquist, M., Baltensperger, U., and Ristovski, Z. D.: Analysis of the hygroscopic and volatile properties of ammonium sulphate seeded and unseeded SOA particles, Atmos. Chem. Phys., 9, 721-732, 
doi:10.5194/acp-9-721-2009, 2009.

Mirme, A., Tamm, E., Mordas, G., Vana, M., Uin, J., Mirme, S., Bernotas, T., Laakso, L., Hirsikko, A., and Kulmala, M.: A widerange multi-channel Air Ion Spectrometer, Boreal Environ. Res., 12, 247-264, 2007.

Nadykto, A. B., Yu, F., and Herb, J.: Towards understanding the sign preference in binary atmospheric nucleation, Phys. Chem. Chem. Phys., 10, 7073-7078, 2008.

O’Dowd, C. D., Lowe, J. A., Smith, M. H., Davison, B., Hewitt, N. C., and Harrison, R. M.: Biogenic sulphur emissions and inferred non-sea-salt-sulphate cloud condensation nuclei in and around Antarctica, J. Geophys. Res, 102, 12839-12854, 1997.

O’Dowd, C. D., Facchini, M. C., Cavalli, F., Ceburnis, D., Mircea, M., Decesari, S., Fuzzi, S., Yoon, Y. J., and Putaud, J.-P.: Biogenically driven organic contribution to marine aerosol, Nature, 431, 676-680, 2004.

Paasonen, P., Sihto, S.-L., Nieminen, T., Vuollekoski, H., Riipinen, I., Plass-Dülmer, C., Berresheim, H., Birmili, W., and Kulmala, M.: Connection between new particle formation and suphuric acid at Hohenpeissenberg (Germany) including the influence of organic compounds, Boreal Environ. Res., 14, 616-629, 2009.

Park, J., Sakurai, H., Vollmers, K., and McMurry, P. H.: Aerosol size distributions measured at the South Pole during ISCAT, Atmos. Environ., 38, 5493-5500, 2004.

Peng, C. and Chan, C. K.: The water cycles of water-soluble organic salts of atmospheric importance, Atmos. Environ., 35, 11831192, 2001a.

Peng, C., Chan, M. N., and Chan, C. K.: The hygroscopic propertis of dicarboxylic and multifunctional acids: Measurements and UNICAF predistions, Environ. Sci. Tech., 35, 4495-4501, 2001b.

Poulain, L., Wu, Z., Petters, M. D., Wex, H., Hallbauer, E., Wehner, B., Massling, A., Kreidenweis, S. M., and Stratmann, F.: Towards closing the gap between hygroscopic growth and $\mathrm{CCN}$ activation for secondary organic aerosols - Part 3: Influence of the chemical composition on the hygroscopic properties and volatile fractions of aerosols, Atmos. Chem. Phys., 10, 37753785, doi:10.5194/acp-10-3775-2010, 2010.

Quant, F. R., Caldow, R., Sem, G. J., and Addison, T. J.: Performance of condensation particle counters with three continuousflow designs, J. Aerosol Sci., 23, S405-S408, 1992.

Quinn, P. K., Coffman, D. J., Bates, T. S., Miller, T. L., Johnson, J. E., Voss, K., Welton, E. J., and Neusüss, C.: Dominant aerosol chemical component and their contribution to extinction during the Aerosols99 cruise across the Atlantic, J. Geophys. Res., 106, 20783-20809, 2001.

Rader, D. J. and Marple, V. A.: Effect of UltraStokesian Drag and Particle Interception on Impactor Characteristics, Aerosol Sci. Technol., 4, 141-156, 1985.

Rolph, G. D.: Real-time Environmental Applications and Display sYstem (READY) Website (http://www.arl.noaa.gov/ready/ hysplit4.html), Silver Spring, MD: NOAA Air Resources Laboratory, 2003.

Saxena, V. K.: Evidence of the biogenic nuclei involvement in Antarctic coastal clouds, J. Phys. Chem., 87, 4130-4134, doi:10.1021/j100244a029, 1983.

Saxena, V. K., Curtin, T. B., and Parungo, F. P.: Aerosol formation by wave action over Ross Sea, Antarctica, J. Rech. Atmos., 19, 213-224, 1985.
Saxena, P., Hildemann, L. M., McMurry, P. H., and Seinfeld, J. H.: Organics alter hygroscopic behavior of atmospheric particles, J. Geophys. Res., 100, 18755-18770, 1995.

Shaw, G. E.: Antarctic aerosols: a review, Rev. Geophys., 26, 89$112,1988$.

Spracklen, D. V., Arnold, S. R., Sciare, J., Carslaw, K. S., and Pio, C.: Globally significant oceanic source of organic carbon aerosol, Geophys. Res. Lett., 35, L12811, doi:10.1029/2008GL033359, 2008.

Stokes, R. H. and Robinson, R. A.: Interactions in aqueous nonelectrolyte solutions. I. Solutesolvent equilibria, J. Phys. Chem., 70, 2126-2130, 1966.

Stolzenburg, M. R. and McMurry, P. H.: An ultrafine aerosol condensation nucleus counter, Aerosol Sci. Technol., 14, 48-65, 1991.

Stolzenburg, M. R.: An ultrafine aerosol size distribution measuring system, Ph. D. Thesis, University of Minnesota, 1988.

Svenningsson, B., Rissler, J., Swietlicki, E., Mircea, M., Bilde, M., Facchini, M. C., Decesari, S., Fuzzi, S., Zhou, J., Mnster, J., and Rosenørn, T.: Hygroscopic growth and critical supersaturations for mixed aerosol particles of inorganic and organic compounds of atmospheric relevance, Atmos. Chem. Phys., 6, 1937-1952, doi:10.5194/acp-6-1937-2006, 2006.

Swietlicki, E., Hansson, H.-C., Hämeri, K., Svenningsson, B., Massling, A., McFiggans, G., McMurry, P. H., Petäjä, T., Tunved, P., Gysel, M., Topping, D., Weingartner, E., Baltensperger, U., Rissler, J., Wiedensohler, A., and Kulmala, M.: Hygroscopic properties of submicrometer atmospheric aerosol particles measured with H-TMDA instruments in various environments - a review, Tellus, 60B, 432-469, 2008.

Tang, I. N.: Chemical and size effects of hygroscopic aerosols on light scattering coefficients, J. Geophys. Res, 101, 19245-19259, 1996.

Teinilä, K., Kerminen, V.-M., and Hillamo, R.: A study of sizesegregated aerosol chemistry in the Antarctic atmosphere, J. Geophys. Res, 105, 3893-3904, 2000.

Timonen, H., Saarikoski, S., Aurela, M., Saarnio, K., and Hillamo, R.: Water-soluble organic carbon in urban aerosol: concentrations, size distributions and contribution to particulate matter, Boreal Environ. Res., 13, 335-346, 2008.

Tomlinson, J. M., Li, R., and Collins, D. R: Physical and chemical properties of the aerosol within the southeastern Pacific marine boundary layer, J. Geophys. Res, 112, D12211, doi:10.1029/2006JD007771, 2007.

Topping, D. O., McFiggans, G. B., and Coe, H.: A curved multicomponent aerosol hygroscopicity model framework: Part 1 - Inorganic compounds, Atmos. Chem. Phys., 5, 1205-1222, doi:10.5194/acp-5-1205-2005, 2005.

Turpin, B. J. and Lim, H.-J.: Species contributions to PM2.5 mass concentrations: revisiting common assumptions for estimating organic mass, Aerosol Sci. Technol., 35, 602-610, 2001.

Turpin, B. J., Saxena, P., and Andrews, E.: Measuring and simulating particulate organics in the atmosphere: problems and prospects, Atmos. Environ., 34, 2983-3013, 2000.

Virkkula, A., Koponen, I. K., Teinilä, K., Hillamo, R., Kerminen, V.-M., and Kulmala, M.: Effective real refractive index of dry aerosols in the Antarctic boundary layer, Geophys. Res. Lett., 33, L06805, doi:10.1029/2005GL024602, 2006a.

Virkkula, A., Teinilä, K., Hillamo, R., Kerminen, V.-M., Saarikoski, 
S., Aurela, M., Koponen, I.K, and Kulmala, M.: Chemical size distributions of boundary layer aerosol over the Atlantic Ocean and at an Antarctic site, J. Geophys. Res, 111, D05306, doi:10.1029/2004JD004958, 2006b.

Virkkula, A., Teinilä, K., Hillamo, R., Kerminen, V.-M., Saarikoski, S., Aurela, M., Viidanoja, J., Paatero, J., Koponen, I. K., and Kulmala, M.: Chemical composition of boundary layer aerosol over the Atlantic Ocean and at an Antarctic site, Atmos. Chem. Phys., 6, 3407-3421, doi:10.5194/acp-6-3407-2006, 2006c.

Virkkula, A., Hirsikko, A., Vana, M., Aalto, P. P., Hillamo, R., and Kulmala, M.: Charged particle size distributions and analysis of particle formation events at the Finnish Antarctic research station Aboa, Boreal Environ. Res., 12, 397-408, 2007.

Volkamer, R., Ziemann, P. J., and Molina, M. J.: Secondary Organic Aerosol Formation from Acetylene $\left(\mathrm{C}_{2} \mathrm{H}_{2}\right)$ : seed effect on SOA yields due to organic photochemistry in the aerosol aqueous phase, Atmos. Chem. Phys., 9, 1907-1928, doi:10.5194/acp9-1907-2009, 2009.

Wang, M. and Penner, J. E.: Aerosol indirect forcing in a global model with particle nucleation, Atmos. Chem. Phys., 9, 239-260, doi:10.5194/acp-9-239-2009, 2009.
Wehner, B., Philippin, S., and Wiedensohler, A.: Design and calibration of a thermodenuder with an improved heatingunit to measure the size-dependent volatile fraction of aerosol particles, J. Aerosol Sci., 33, 1087-1093, 2002.

Winkler, P. M., Steiner, G., Vrtala, A., Vehkamäki, H., Noppel, M., Lehtinen, K. E. J., Reischl, G. P., Wagner, P. E., and Kulmala, M.: Heterogeneous nucleation experiments bridging the scale from molecular ion clusters to nanoparticles, Science, 319 , 1374-1377, 2008.

Winklmayr, W., Reischl, G. P., Linder, A. O., and Berner, A.: A new electromobility spectrometer for the measurement of aerosol size distributions in the size range from 1 to $1000 \mathrm{~nm}$, J. Aerosol Sci., 22, 289-296, 1991.

Wise, E. W., Surratt, J. D., Curtis, D. B., Shilling, J. E., and Tolbert, M. A.: Hygroscopic growth of ammonium sulfate/dicarboxylic acids, J. Geophys. Res., 108, 4638, doi:10.1029/2003JD003775, 2003.

Yli-Juuti, T., Riipinen, I., Aalto, P. P., Nieminen, T., Maenhaut, W., Janssens, I. A., Claeys, M., Salmsa, I., Ocskay, R., Hoffer, A., Imre, K., and Kulmala, M.: Characteristics of new particle formation events and cluster ions at K-puszta, Hungary, Boreal Environ. Res., 14, 683-698, 2009. 